\title{
Megafaunal Ecology of the Western Clarion Clipperton Zone
}

\begin{abstract}
Jennifer M. Durden $1,2 *$, Meagan Putts ${ }^{2}$, Sarah Bingo ${ }^{2}$, Astrid B. Leitner $r^{2,3}$, Jeffrey C. Drazen ${ }^{2}$, Andrew J. Gooday ${ }^{1,4}$, Daniel O. B. Jones ${ }^{1}$, Andrew K. Sweetman ${ }^{5}$, Travis W. Washburn ${ }^{2}$ and Craig R. Smith ${ }^{2}$

'National Oceanography Centre, Southampton, United Kingdom, ${ }^{2}$ Department of Oceanography, University of Hawai $i$ at Mānoa, Honolulu, HI, United States, ${ }^{3}$ Monterey Bay Aquarium Research Institute, Moss Landing, CA, United States, ${ }^{4}$ Life Science Department, Natural History Museum, London, United Kingdom, ${ }^{5}$ The Lyell Centre for Earth and Marine Science, Heriot-Watt University, Edinburgh, United Kingdom
\end{abstract}

\section{OPEN ACCESS}

Edited by:

Pedro A. Ribeiro,

University of Bergen, Norway

Reviewed by:

Lenaick Menot,

Institut Français de Recherche pour

l'Exploitation de la Mer (IFREMER),

France

Akkur Vasudevan Raman,

Andhra University, India

*Correspondence:

Jennifer M. Durden

jennifer.durden@noc.soton.ac.uk

Specialty section:

This article was submitted to

Deep-Sea Environments and Ecology,

a section of the journal

Frontiers in Marine Science

Received: 22 February 2021 Accepted: 24 May 2021

Published: 01 July 2021

Citation:

Durden JM, Putts M, Bingo S, Leitner AB, Drazen JC, Gooday AJ,

Jones DOB, Sweetman AK, Washburn TW and Smith CR (2021) Megafaunal Ecology of the Western

Clarion Clipperton Zone.

Front. Mar. Sci. 8:671062. doi: 10.3389/fmars.2021.671062
The Clarion Clipperton Zone (CCZ) is a vast area of the central Pacific Ocean where the abyssal seabed is a focus for future polymetallic nodule mining. Broad-scale environmental gradients occur east-to-west across the CCZ seabed, including organic matter supply and nodule abundance, factors that influence benthic faunal community structure and function. A network of protected areas across the CCZ, called Areas of Particular Environmental Interest (APEIs), has been designated to cover this variation. Most previous studies of the benthic environment and megafaunal communities have focussed on the eastern CCZ, leaving the impact of these large-scale gradients unexamined and the network design untested. Seamounts are a further source of heterogeneity in the region. We examined the benthic megafaunal ecology of three APEls in the western CCZ, spanning a range of environmental conditions. We used a combination of seabed photography and direct sampling to assess the environment and megafauna on the soft sediment habitats on the abyssal plain in three APEls, and seamounts in two of those APEls. We found that environmental conditions on abyssal plains differed between the three APEls in terms of water depth, nodule abundance and coverage, sediment particle size distribution, and estimated organic matter flux. Megafauna were low density and high diversity, with few common morphotypes between sites and many morphotypes being observed only once. Xenophyophores dominated the assemblages. The density and diversity of invertebrates were greater at the sites with lower organic matter inputs and greater nodule abundance. Seamounts in the same APEls were nodule-free and had coarser sediments than on the plain. Invertebrate megafaunal diversity was lower on the seamounts than on the plains, and most morphotypes recorded on the seamounts were only found on seamounts. Low morphotype overlap also suggests little connectivity between APEls, and between seamounts and adjacent abyssal plains. Our results provide the first evaluation of the seabed habitats and megafaunal ecology in the western CCZ, highlighting environmental gradients that influence benthic communities, and are important for evaluating the design of the network of protected areas.

Keywords: seamount, beta-diversity, polymetallic nodule, seabed mining, abyssal plain, Area of Particular Environmental Interest, Marine Protected Area, regional environmental management 


\section{INTRODUCTION}

The abyssal seabed of the Clarion Clipperton Zone (CCZ) covers 6 million $\mathrm{km}^{2}$ of the central Pacific Ocean and has become a focus for future deep-sea polymetallic nodule mining (Lodge et al., 2014). Large-scale gradients of environmental conditions occur across the CCZ, in east-to-west and north-to-south directions (Smith and Demopoulos, 2003; Wedding et al., 2013; Washburn et al., 2021a). These environmental conditions include the seabed substrate and the organic matter supply to the benthos, factors that influence the abundance, diversity, community composition and ecosystem function of deep-sea benthic faunal communities (Smith et al., 1997, 2008, 2009; Ruhl and Smith, 2004; Ruhl et al., 2008; Lacharité and Metaxas, 2017; Simon-Lledó et al., 2020). Across the CCZ, polymetallic nodule abundance and organic matter flux are generally higher in the east than in the west, and the abyssal seabed is deeper to the west (Wedding et al., 2013; Washburn et al., 2021a). The majority of studies of the CCZ, particularly in the last decade, have focused on the eastern portion. Several of these studies highlight the high diversity of benthic megafauna, a faunal group important to ecosystem function (Smith et al., 2008), of the eastern CCZ (e.g., Amon et al., 2016, 2017; Vanreusel et al., 2016; Gooday et al., 2017a,b,c, 2018a; Leitner et al., 2017; Simon-Lledó et al., 2019a; Cuvelier et al., 2020; Harbour et al., 2020; Jones et al., in review). The influence of substrate locally on the benthos in areas of the eastern CCZ was evident in these studies, particularly that of soft sediment texture, and nodule presence and size (Vanreusel et al., 2016; Simon-Lledó et al., 2019b). However, peer-reviewed studies on the benthic megafauna to the west remain few, even when those conducted outside the CCZ are included (e.g., Smith et al., 1997; Simon-Lledó et al., 2019c), or are focused on a single taxonomic or functional group (e.g., Leitner et al., 2017, 2020a; Gooday et al., 2020a,b). Thus, our understanding of the roles of environmental conditions in influencing megafaunal community structure and function, and their variation across the $\mathrm{CCZ}$, is incomplete.

Bathymetric features are a source of heterogeneity in the seabed environment. Features providing positive elevation above the seabed, such as seamounts, are common on abyssal plains and specifically in the far western and eastern areas of the CCZ (Yesson et al., 2011; Wedding et al., 2013; Harris et al., 2014; Washburn et al., 2021a). Large variations in seabed environmental conditions found on seamounts, particularly those related to substrate and organic matter availability, influence the benthic communities present (Fock et al., 2002; Piepenburg and Muller, 2004; Samadi et al., 2007; Clark et al., 2009; McClain et al., 2009; Bo et al., 2011; Williams et al., 2011, 2015; Boschen et al., 2015; Rogers, 2018; Morgan et al., 2019; Cuvelier et al., 2020; Jones et al., in review). Current speeds are enhanced and directions altered around seamounts (Genin et al., 1986), resulting in enhancements to suspended particle flux and locally deposited organic matter (Kiriakoulakis et al., 2009; Vilas et al., 2009). Because seamount summits are shallower than the surrounding abyssal plain, the POC flux to the seabed may also be higher (Lutz et al., 2007). The enhanced currents can also alter the substrate texture, winnowing fine material and exposing hard substrate. Most studies on the megafauna of seamounts in relation to substrate focus on the availability of hard substrate, with little examination of soft sediment habitats. However, studies of smaller elevated features, such as knolls and abyssal hills, show that even subtle differences in elevation produce changes in soft sediments that have a large influence on megafaunal community diversity, standing stocks and assemblage composition (Durden et al., 2015, 2020b; Turnewitsch et al., 2015; Milligan et al., 2016; Leitner et al., 2017).

The governance of future polymetallic nodule mining by the International Seabed Authority (ISA) has included the development of a spatial environmental management plan (the "Regional Environmental Management Plain") for the CCZ, which designated areas to be protected from seabed mining. A network of these "Areas of Particular Environmental Interest" (APEIs) was designed to represent the environmental gradients across the CCZ (Wedding et al., 2013; Lodge et al., 2014). In addition, the APEIs were originally intended (Wedding et al., 2013) to represent similar habitats to those found in areas designated for mining. However, there has been very limited study of seafloor communities within APEIs; only small portions of some APEIs have been studied, leaving in question the extent to which this objective has been met. The APEIs in the western CCZ were located to span areas of high to low predicted nodule abundance, and moderate to low seabed organic matter supply. Recent studies have investigated APEIs in the eastern CCZ (Vanreusel et al., 2016; Simon-Lledó et al., 2019a; Jones et al., in review), but none have yet been conducted in the APEIs in the western CCZ.

Here, we report on the benthic megafaunal ecology of the abyssal plains in three APEIs in the western CCZ and examine the results in a regional context. We hypothesise that environmental conditions differ in the three abyssal plain areas, in terms of physical habitat (bathymetry, sediment conditions and nodule characteristics), in addition to known differences in resource (organic matter) inputs. We aim to determine whether standing stocks, diversity and assemblage structure of the invertebrate megafauna and highly mobile scavengers/predators differ across the region in response to these environmental gradients. We compare soft sedimented habitats on seamounts adjacent to these abyssal sites, and examine differences from the abyssal plain in both the sedimentary environment and faunal assemblages. We test these hypotheses using seabed photography and direct sampling of the sedimentary environment. We then use these data to comment on potential relationships between habitat heterogeneity and megafaunal assemblages in terms of regional variation (beta-diversity) across the western $\mathrm{CCZ}$, and the potential for connectivity within and between habitats. Finally, we set these data in the contexts of regional variation across the whole CCZ, and conditions in nearby mining exploration areas, and comment on the suitability of these APEIs as part of regional environmental management of polymetallic nodule mining and conservation in the CCZ. 


\section{MATERIALS AND METHODS}

\section{Field Site Selection}

Field operations in the western CCZ were conducted from the RV Kilo Moana between May 14 and June 16, 2018, as part of the DeepCCZ project, which included assessment of the benthic and benthopelagic environments and communities across an range of size classes from microbes to megafauna as well as ecosystem function (Drazen et al., 2019). Operations for this study were conducted using the remotely operated vehicle (ROV) Lu'ukai.

Field sites were selected in each of the three APEIs in the western CCZ (APEIs 1, 4, and 7), and included a location on the abyssal plain in each, and a location on a proximate seamount in APEIs 4 and 7 (Figure 1). Practical constraints precluded the examination of a seamount in APEI-1 for this study. Similar site locations were selected across the APEIs based on several criteria: (1) Site locations were selected to be within the CCZ. (2) Central location within the APEI was preferred, with locations in the APEI perimeter "buffer zone" (as described by Wedding et al., 2013) avoided, if possible. In order to meet the other criteria in APEI 1, the study site was located in the southern buffer zone. (3) Predicted high nodule abundance on the abyssal plain based on geological modelling (International Seabed Authority, 2010; Wedding et al., 2013) was preferred, so that abyssal plain sites would be comparable to those in areas to be mined. (4) The presence of a suitable seamount with an area of abyssal plain outside the presumed zone of seamount influence was required. The zone of influence was estimated to extend outwards from the seamount base for $15 \mathrm{~km}$, based on a maximum influence of $30 \mathrm{~km}$ from the summit for very large seamounts with shallow summit depths (Gove et al., 2016). (5) Suitable seamounts each had a summit rising a minimum of $1,000 \mathrm{~m}$ above the abyssal plain estimated from satellite bathymetry (SRMT30+), with a "flat" area likely containing soft sediment near the top. Similar summit water depths and geomorphologies between seamounts were preferred, confirmed with shipboard multibeam.

\section{Photo Capture and Processing}

Seabed images were captured for the assessment of both the seabed environment and the megafaunal community (Table 1). ROV transects were undertaken at a randomly selected heading within the range of headings allowed by environmental conditions (surface winds and currents, bottom currents) and topography, with the aim of minimising suspended sediment from obscuring collected imagery and facilitating reasonable ship movement. Seabed transects at each location were planned to be $2 \mathrm{~km}$ in length on abyssal plains and $1 \mathrm{~km}$ on seamounts, at a target speed over ground of 0.5 knots, with a target camera altitude of $2.62 \mathrm{~m}$ above bottom. Still images were captured at 10-s intervals with a downward-facing Ocean Imaging Systems DSC 24000 digital camera system mounted to the front of the Lu'ukai ROV (Nikon 7100 camera set to aperture F8, shutter speed 1/60, focal distance 8.5 feet, images 4,000 $\times 6,000$ pixels). Dedicated lighting was provided by two Ocean Imaging Systems $300 \mathrm{~W}-\mathrm{S}$ remote head strobes synchronised to the camera shutter. Parallel lasers at a separation of $350 \mathrm{~mm}$ were used for scaling in the imagery.

Seafloor photos were examined if they met the following criteria: captured at camera altitudes up to $3 \mathrm{~m}$ above the seabed; ROV pitch and roll between -5 and 5 degrees; no overlap between photos; no obscuration (e.g., by large shadows or suspended sediment). The selected photos were cropped to $3,000 \times 6,000$ pixels to remove obscuration from ROV equipment in the image, and colour-corrected to approximate true-to-life colour in a well-lit environment. Annotations of photos was completed using the Monterey Bay Aquarium Research Institute's Video and Annotation Referencing System (Schlining and Stout, 2006).

\section{Assessment of Environmental Characteristics}

Four aspects of the benthic environment were examined: seabed bathymetry, estimated organic matter flux at the seabed, nodule abundance and sediment particle size. Seabed bathymetry was measured using a ship-borne multibeam echosounder $(12 \mathrm{kHz}$ Simrad EM120, Kongsberg Maritime), with a swath width of 12-14 km. Measured bathymetry was processed onboard using Qimera software (Quality Positioning Services), gridded at 100 $\mathrm{m}$, with a correction for the sound velocity profile applied. Organic matter flux to the abyssal seabed was estimated as particulate organic matter (POC) flux for the study sites by Leitner et al. (2020a) based on a model by Lutz et al. (2007). POC flux to the seamount summits was not estimated because the coarse bathymetric model used by Lutz et al. (2007) to estimate of seafloor POC flux does not reliably capture seamount summit depth.

The density, seabed cover, and individual sizes of nodules were assessed in a randomly selected subset of 1090 seabed photographs (Table 1). A single annotator enumerated and measured all nodules in the central portion of each image in the subset $\left(2,000 \times 1,500\right.$ pixels; representing $\sim 0.92 \mathrm{~m}^{2}$ seabed $)$, a size selected for the practicality of annotating images with high densities of nodules.

Sediment was collected in pushcores $(70 \mathrm{~mm}$ internal diameter) deployed by the ROV at locations near the seabed photograph transects (Table 1). Particle size distributions were determined by laser diffraction using a Malvern Mastersizer on the refrigerated collected sediment (0-50 $\mathrm{mm}$ horizon) suspended in reverse osmosis water (i.e., without digestion), following the removal of any nodules. Particle size distributions were divided into three size ranges for analysis, to divide the major modes in the distributions: fine particles $(<17.5 \mu \mathrm{m})$, intermediate-sized particles $(17.5-174 \mu \mathrm{m})$ and coarse particles $(>174 \mu \mathrm{m})$.

\section{Megafaunal Community Assessment}

Megafauna (generally $>10 \mathrm{~mm}$ in dimension, sensu Grassle et al., 1975) were enumerated in the photos and classified to the most detailed taxonomic level possible based on previously published studies of megafauna in the CCZ (Figures 2, 3; Simon-Lledó et al., 2019a,b,c; Cuvelier et al., 2020; 

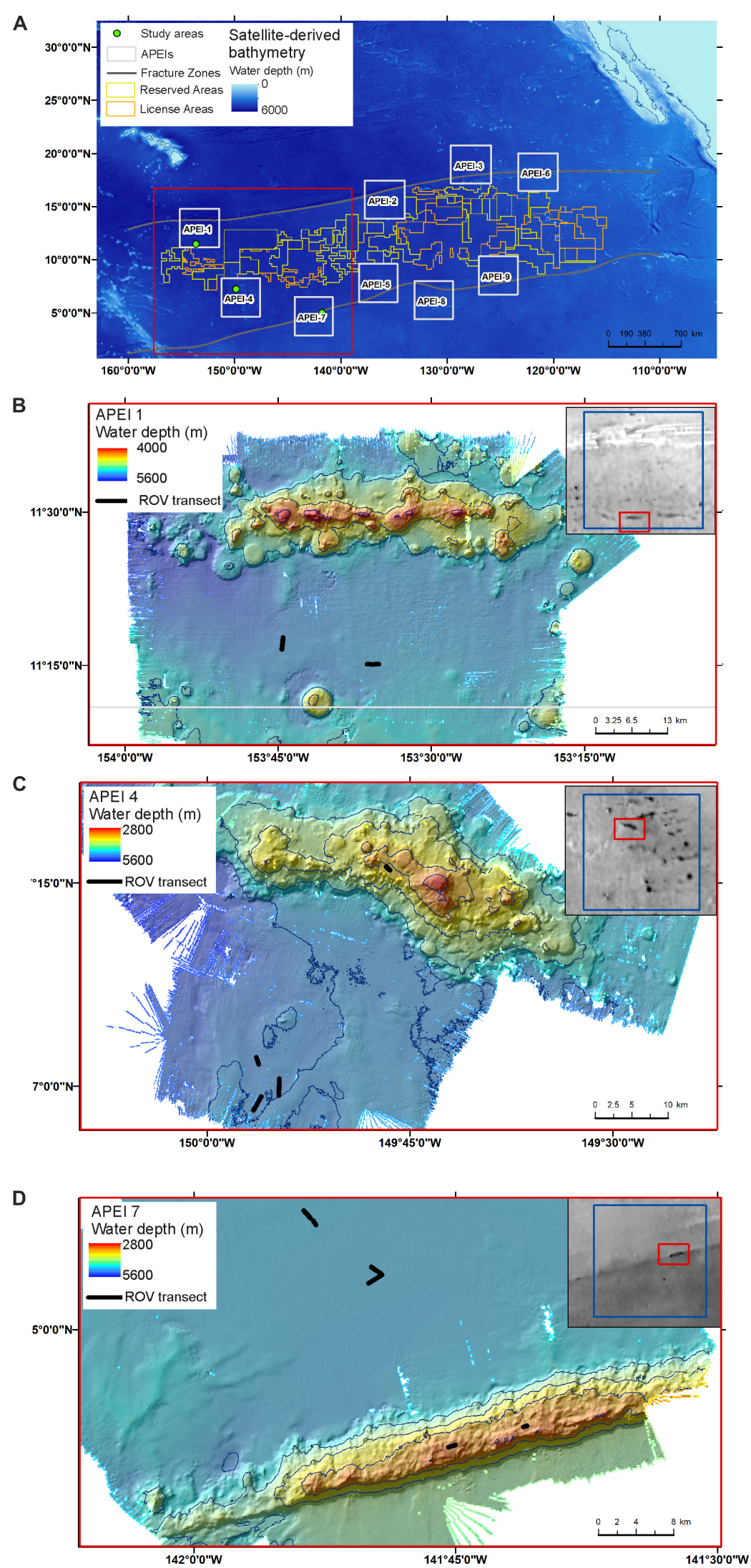

FIGURE 1 | Maps of the region (A), and of the study areas in (B) APEI-1, (C) APEI-4, and (D) APEI-7. 
TABLE 1 | Sediment coring and photographic transect information for the study sites in the western CCZ. Four sample units were created of 73 photos for nodule coverage and 312 photos for megafauna on the abyssal plain; on the seamounts, those sample unit sizes could not be achieved (indicated by ${ }^{\star}$ ).

\begin{tabular}{|c|c|c|c|c|c|}
\hline \multirow[b]{2}{*}{ Location } & \multicolumn{3}{|c|}{ Abyssal plain } & \multicolumn{2}{|c|}{ Seamount } \\
\hline & APEI-1 & APEI-4 & APEI-7 & APEI-4 & APEI-7 \\
\hline Centre latitude $\left(^{\circ}\right)$ & 11.252 & 6.994 & 5.058 & 7.267 & 4.889 \\
\hline Centre longitude $\left(^{\circ}\right)$ & -153.604 & -149.935 & -141.827 & -149.777 & -141.753 \\
\hline Water depth (m) & $5,198-5,251$ & $4,999-5,039$ & $4,855-4,873$ & $3,538-3,570$ & $3,095-3,247$ \\
\hline Seabed photos for megafaunal assessment & 1,250 & 1,706 & 1,347 & 233 & 325 \\
\hline Seabed area photographed for megafaunal assessment $\left(\mathrm{m}^{2}\right)$ & 6,767 & 9,529 & 7,277 & 1,341 & 1,739 \\
\hline Seabed photos for nodule assessment & 310 & 368 & 295 & 51 & 66 \\
\hline No. photo sample units & 4 & 5 & 4 & $1^{*}$ & $1^{*}$ \\
\hline No. nodules measured & 10,117 & 2,862 & 0 & 0 & 0 \\
\hline Sediment cores & 3 & 4 & 3 & 1 & 1 \\
\hline
\end{tabular}

Kahn et al., 2020). A six-digit alphanumeric code was assigned to each morphotype. Highly mobile scavengers and predators, and monothalamous Foraminifera (Xenophyophoroidea) were treated separately from the remaining "invertebrate megafauna" (see below), and additional investigations were made of key taxonomic groups (i.e., echinoderms, porifera and cnidarians).

Prepared seabed photos $(3,000 \times 6,000$ pixels $)$ were randomly assigned to two experts for megafaunal annotation. In addition to randomising the collections and order of images annotated by each expert, the following steps were taken to reduce annotator bias: (1) Prior to annotation of the main photo set, a subset of images was annotated by both experts, and their detections and classifications of megafauna in this "training" image set were discussed. These annotation data were removed and the images returned to the image pool. (2) Subsets of photos were randomly selected for repeated annotation for assessment and reduction of both inter- and intra-annotator bias in detection and classification of specimens. (3) Following annotation, all identified specimens were reviewed by a single expert on a morphotype basis, and reclassified where necessary to ensure consistency. Annotated counts are provided in Supplementary Material 1.

Individual body size $(\mathrm{mm})$ was measured in each specimen in the images. Taxon-specific measurements (Durden et al., 2016a) were made for morphotypes with at least four individuals at each of a minimum of two sites. Fresh wet weight biomass was estimated for echinoderms (Holothuroidea, Crinoidea, Ophiuroidea, Asteroidea, and Echinoidea) from these measured dimensions in the seabed photographs and established length-towet weight relationships (Durden et al., 2016a). In the case of echinoids, fresh wet weight was estimated based on a spherical test volume of measured diameter, with an estimated tissue volume of $25 \%$ of test volume (Ebert, 2013) converted to fresh mass, assuming a density of $1 \mathrm{~g} \mathrm{~cm}^{-3}$, a method similar to that employed by Durden et al. (2019).

Megafaunal xenophyophores were enumerated in the seabed photographs (as described above), with identification based on published literature on xenophyophores from the CCZ (Gooday et al., 2017a,b,c, 2018a,b). New morphotypes have been observed in seabed images (Gooday et al., 2020a), and new genera and species have been identified from specimens collected at these sites (Gooday et al., 2020b). The maximum diameter of a subset of 8750 specimens were measured in randomly selected images.

Highly mobile scavengers and predators of interest consisted of highly mobile benthopelagic morphotypes, including all fishes, shrimp-like arthropods and octopus. Individuals of these morphotypes were enumerated in seabed photographs (as described above), and classified based on (Drazen et al., in review). These morphotypes were treated separately to facilitate comparisons with other studies, since many megafaunal assessments omit these taxa, while studies using bait, including those from the wider DeepCCZ project, focus on them (Leitner et al., 2020a; Drazen et al., in review).

\section{Statistical Comparisons Between APEls}

Statistical comparisons of conditions on the abyssal plain were made between APEIs by creating sample units from the set of pooled photos across all transects in an APEI. For statistical comparisons of nodule parameters, annotation data from the abyssal plain locations were aggregated into a minimum of four sample units of 73 randomly selected photographs each, the maximum sample unit size for the smallest nodule image set per APEI (Table 1; 295 photographs for nodule assessment at APEI-7). Mean fine, medium and coarse sediment content was computed across cores collected from a site. For statistical comparisons of density, diversity, echinoderm biomass, and community composition, annotation data from the abyssal plain locations were aggregated into a minimum of four sample units of 312 randomly selected photographs, the maximum sample unit size for the smallest image set per APEI (Table 1; 1250 seabed photos for megafaunal assessment at APEI-1). Comparisons of individual body size were conducted on a specimen basis. Although the limited photography and sampling on seamounts precluded statistical comparisons, all photographs captured at each seamount were aggregated into a single unit to facilitate computation of ecological metrics. 


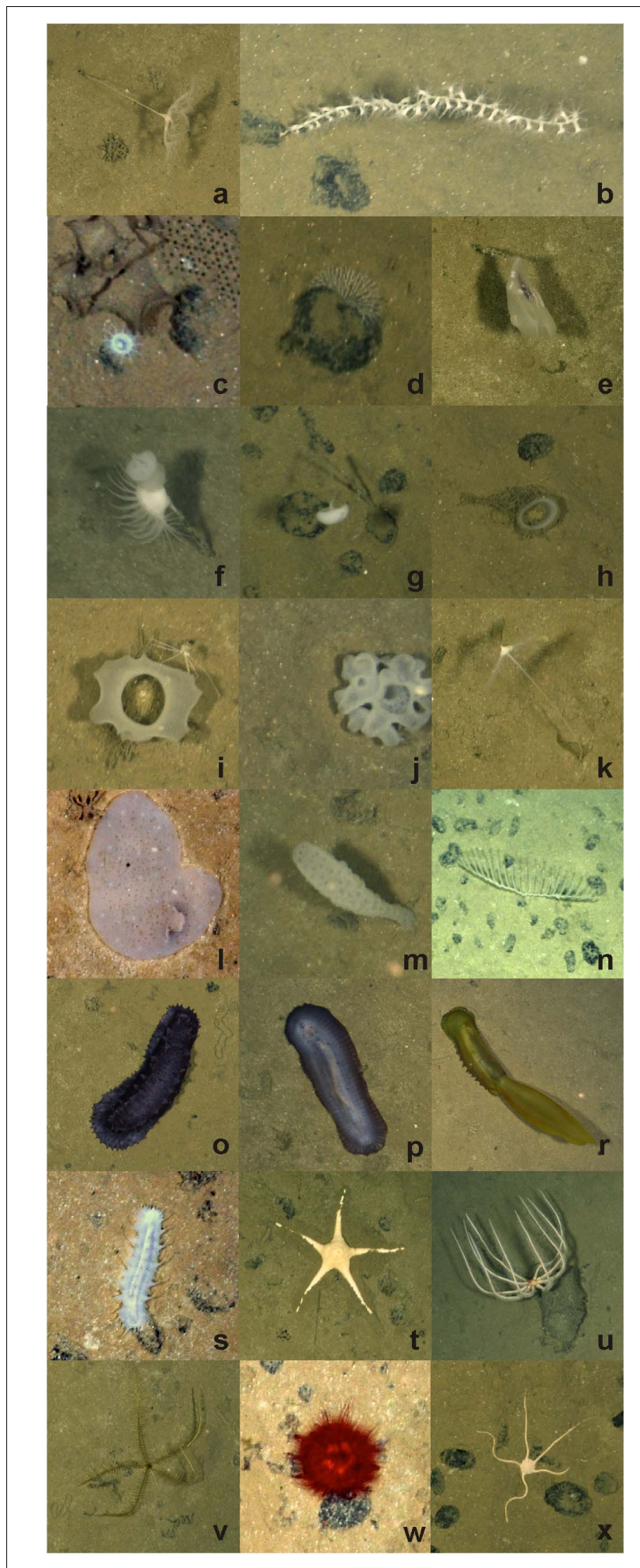

FIGURE 2 | Select invertebrate megafaunal specimens photographed on the abyssal plain in study areas of the western CCZ, with identifications and morphotype codes: (a) Umbellula sp. PEN003, (b) Isididae ALC005, (c) actiniarian ACT022 with large xenophyophore and Paleodictyon trace to top right; (d) Bryozoa BRY002; Ctenophora (e) Lyrocteis sp. CTE010; Porifera

(Continued)

\section{FIGURE 2 | Continued}

(f) Hyalonema sp. POR030 with Actiniaria ACT042, (g) Caulophacus sp. HEX027 and nodules, (h) Acanthascus sp. HEX029, (i) Euplectella sp. HEX019 with Isopoda, (j) Placopegma sp. HEX005, (k) Cladorhizidae DES012, (I) Docosaccus sp. HEX015, (m) Euplectellinae sp. HEX011, (n) Chondrocladia (Symmetrocladia) cf. Iyra DES014; Holothuroidea (o) Galatheathuria sp. HOL038, (p) Benthodytes sp. HOLO42, (r) Psychropotes cf dyscrita HOL047, (s) Synallactidae HOL007; Asteroidea (t) Dytaster sp. AST005, (u) Brisingida AST001; (v) Pentametrocrinidae CRI002; Echinoidea (w) Kamptosoma sp. URC013; (x) Ophiuroidea OPH010. Image attribution: JM Durden \& CR Smith, University of Hawai'i.

Nodule and faunal abundance, and echinoderm biomass were standardised to unit seabed area. Univariate Hill's diversity indices $(\mathrm{Nq})$, morphotype richness $(q=0)$, exponential of the Shannon index $(q=1)$, and the inverse of the Simpson's index $(q=2$; Magurran, 2013) were computed along with the rarefied number of morphotypes (Hurlbert, 1971) at the minimum number of individuals in any sampling unit (65). Environmental and univariate ecological metrics on the abyssal plains were compared between APEIs using ANOVA, with significance reported at $\alpha=0.05$ and post hoc testing using Tukey's honest significant difference. Normality was tested by visual inspection of normal quantile plots, and the Shapiro-Wilk normality test. Percentage data were arcsine transformed before assessment. Accumulation curves were computed for median values of density and diversity indices over aggregated images, repeated 500 times.

Differences in apparent assemblage composition were assessed using multivariate statistics (Bray-Curtis dissimilarity measure and 2-dimensional non-metric multidimensional scaling ordination), with the sample unit-like groupings of photographic data on the seamounts included in multidimensional analyses for illustration. Statistical comparisons between the community data on the abyssal plains were tested using ANOSIM and SIMPER routines (Clarke, 1993). All ecological metrics were calculated using the vegan package in $\mathrm{R}$ (Oksanen et al., 2012).

\section{RESULTS}

\section{Environmental Characteristics Abyssal Plains}

The study sites were located in the three westernmost APEIs in the CCZ (Figure 1), with APEI-1 being the most northerly and westerly, and APEI-7 being the most easterly and southerly of the three. In APEI-1, the study site was located in the centre-south portion of the APEI, in a position between an elongated ("ridgelike") seamount to the north and a conical seamount to the south. In APEI-4, the study site was in centre-north portion of the APEI, and in APEI-7, the study site was in the northeast portion of the APEI. Seabed water depth across the region increased from east to west (Table 2), though the bathymetry between the APEI study sites is largely unknown, as these were the first seabed mapping exercises in these APEIs and large deviations from satellitederived bathymetry were observed (e.g., presence or absence of large seamounts in contrast to anticipated bathymetry). The 


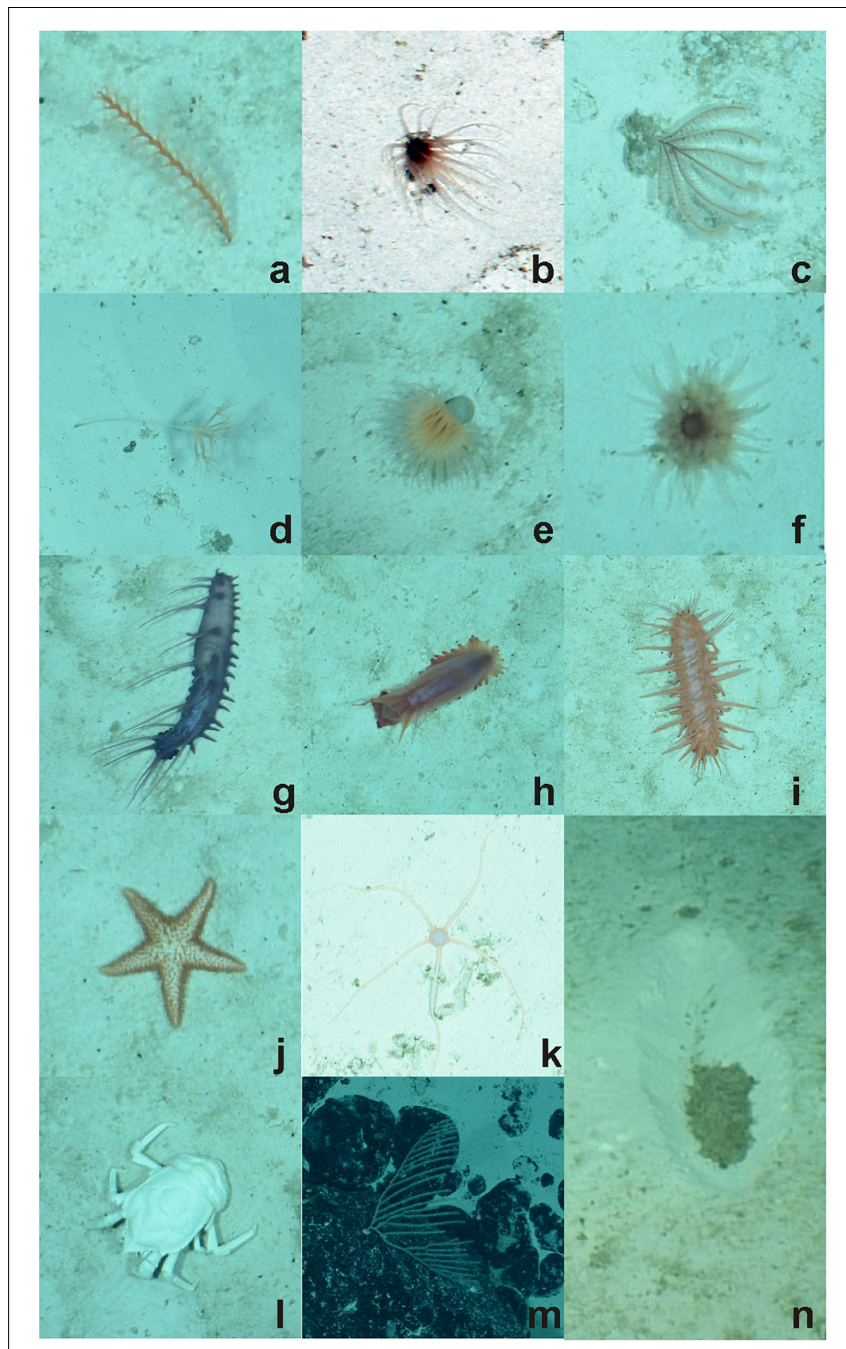

FIGURE 3 | Select invertebrate megafaunal specimens photographed on the seamount study areas in the western CCZ: Cnidaria (a) Protoptilum sp. PEN017, (b) Cerianthidae CER001, (c) Heteropathes cf. americana ALC021, (d) Umbellula sp. PEN012 with ripples in sediment, (e) Actiniaria ACT043, (f) Actiniaria ACT012; Holothuroidea: (g) Laetmogone sp. HOL030, (h) Peniagone sp. HOL064, (i) Deimatidae HOL060; (j) Asteroidea AST024; (k) Ophiuroidea OPH012; (l) Galatheoidea DEC007, (m) Actiniaria ACT011 on basalt-type hard substrate, $(\mathbf{n})$ large depression in soft sediment $(\sim 0.5 \times 1.5$ m). Image attribution: JM Durden and CR Smith, University of Hawai'i.

seabed on the abyssal plain observed during seabed transects was "flattest" at APEI-7 (elevation difference of $18 \mathrm{~m}$ ), while elevation differences at least double that $(40$ and $53 \mathrm{~m}$ ) were found at APEIs 4 and 1, respectively (Table 1). Estimated POC flux at the abyssal seabed decreased from southeast to northwest across the western CCZ (Table 2).

Sedimentary conditions differed between the areas studied in the APEIs (Table 2 and Figure 4). Nodule density (number $\mathrm{m}^{-2}$ ) was significantly different between the APEI study sites [ANOVA $F(2,10)=141.9, p<0.001]$. The nodule density observed in APEI-1 was four times that in APEI-4, while no nodules were observed in APEI-7. Seabed cover by nodules was significantly different in the areas studied in each APEI $[F(2,10)=187.3$, $p<0.001$ ], and significantly higher in APEI-1 than in APEI4 study sites. Mean nodule size (plan area; $\mathrm{mm}^{2}$ ) measured in seabed photographs was significantly larger in the study sites in APEI-1 than in APEI-4 $[F(1,12977)=734.4, p<0.0001]$. The observed nodule occurrence was patchy, with areas without nodules observed at APEIs 1 and 4, and nodule densities ranging over two orders of magnitude at APEI-1 (Figure 4).

Sediments (excluding nodules) were dark brown in colour (Figure 2 and Supplementary Material 2) from the sediment surface to the full depth collected $(\sim 150-200 \mathrm{~mm})$, except in some cores collected at APEI-4, where a colour change to lighterbrown sediment was observed at approximately $100 \mathrm{~mm}$ core depth (Supplementary Material 2). Particle size distributions had two main peaks (Figure 4), the greatest at $80 \mu \mathrm{m}$ (in the intermediate size range) and a lesser peak at $8 \mu \mathrm{m}$ (in the fine size range). The fraction of fine sediments on the plain differed between the APEIs [Table 2; $F(2,7)=16.8, p<0.01$ ], as was the fraction of intermediate-sized particles $[F(2,7)=12.4, p<0.01]$, and the coarse sediments $[F(2,7)=14.1, p<0.01]$. Sediments at APEI-1 had the highest fine particle content and the smallest fraction of intermediate-sized particles, those at APEI-4 had the greatest proportion of intermediate-sized particles, and those at APEI-7 had the least fine particle content (Figure 4).

In summary, a gradient of environmental conditions was observed across the three locations. At the most northwesterly location (APEI-1), the water depth of the abyssal plain was deepest, estimated POC flux was lowest, nodule density and cover were highest, nodules were largest, and sediment grains were finest. APEI-4 exhibited intermediate conditions, including lower nodule density and cover, and smaller nodules. In APEI-7, the seabed water depth was shallowest, estimated POC flux was greatest, nodules were absent, and sediment grains were coarsest.

\section{Seamounts}

Both seamounts were ridge features with similar geomorphologies (Figure 1), in contrast to conical features also found in the APEIs. The seamount summit in APEI-4 was at 2,800 $\mathrm{m}$ water depth, and was deeper at the seamount in APEI-7, at 2,936 $\mathrm{m}(1,452$ and 1,744 $\mathrm{m}$ above the abyssal plain, respectively).

The benthic environments at the seamount sites differed substantially from those of the plain. Both were in areas of soft sediment near the ridge of the seamount, with areas of basaltlike hard substrate nearby. No nodules were present. Seamount sediments were a globigerina ooze of white calcareous planktonic foraminifera (Supplementary Material 3), with ripples evident. Particle size distributions on the seamounts were different from those on the plain. They were dominated by very coarse particles, with a peak at $480 \mu \mathrm{m}$ in both APEIs (Table 2 and Figure 4). Lesser peaks in particle size distributions occurred at approximately 120 and $11 \mu \mathrm{m}$.

The environments at the two seamount sites also differed from one another. The site on the seamount at APEI-4 was $439 \mathrm{~m}$ deeper than the site on the seamount at APEI-7 (Table 2). The former was relatively flat (32 m elevation difference; Table 1), while the latter was sloping (152 m elevation difference), with 
TABLE 2 | Environmental characteristics of the study areas by APEl and habitat type.

\begin{tabular}{|c|c|c|c|c|c|}
\hline \multirow[b]{2}{*}{ Location } & \multicolumn{3}{|c|}{ Abyssal plain } & \multicolumn{2}{|c|}{ Seamount } \\
\hline & APEI-1 & APEl-4 & APEI-7 & APEI-4 & APEI-7 \\
\hline Mean seabed water depth (m) & 5,222 & 5,013 & 4,866 & 3,561 & 3,122 \\
\hline Estimated seafloor POC flux $\left(\mathrm{gC}_{\text {org }} \mathrm{m}^{-2} \mathrm{y}^{-1}\right)$ & 1.1 & 1.4 & 1.8 & Not estimated & Not estimated \\
\hline Mean [95\% confidence interval] fine $(<17.5 \mu \mathrm{m})$ sediment content (\%) & $46.3[42.0,50.6]$ & $40.5[38.9,42.0]$ & $39.0[37.8,40.1]$ & 15.2 & 15.8 \\
\hline Mean [95\% confidence interval] coarse (>174 $\mu \mathrm{m})$ sediment content (\%) & $0.7[0.4,1.1]$ & $1.3[1.0,1.6]$ & $2.5[1.8,3.2]$ & 45.8 & 44.6 \\
\hline Median nodule size (plan area; $\mathrm{mm}^{2}$ ) & 744 & 226 & NA & NA & NA \\
\hline Mean [95\% confidence interval] nodule density (counts $\mathrm{m}^{-2}$ ) & $34.6[30.0,39.1]$ & $8.2[5.8,10.5]$ & 0 & 0 & 0 \\
\hline Mean [95\% confidence interval] seabed nodule cover (\%) & $3.3[2.9,3.8]$ & $0.4[0.3,0.5]$ & 0 & 0 & 0 \\
\hline
\end{tabular}

*Estimated particulate organic matter flux from Leitner et al. (2020a) and Washburn et al. (2021a) based on Lutz et al. (2007). The numbers and sizes of photo sample units or cores are given in Table 1.

clumps of phytodetritus visible, and large depressions in the sediment (Figure 3). Sediments on the seamount in APEI-4 were somewhat coarser than those on the seamount in APEI7 (Table 2).

\section{Abyssal Plain \\ Metazoan Invertebrates \\ Density}

Total invertebrate megafaunal density was significantly different between the areas studied in the APEIs [ANOVA $F(2,10)=13.7$, $p<0.01$; Table 3]. These differences were driven by significantly lower density at APEI-7 than at APEIs-1 and 4 (both $p<0.01$; Tukey's HSD).

\section{Diversity}

A total of 126 morphotypes were detected at the abyssal plain sites. Similar numbers of morphotypes were found at APEIs 1 and 4 ( 81 and 80 , respectively), while only 49 were found at APEI-7. Only about one sixth of all morphotypes (22) were found in all study areas (Figure 5). Many taxa were rare, with 34 morphotypes were only detected once. These morphotypes were spread across many taxonomic groups (e.g., Porifera, Holothuroidea, Asteroidea). APEIs 1 and 4 shared more than 3 times as many morphotypes as APEIs 4 and 7. Morphotypes from across all taxonomic groups were identified that were only found at each APEI study area.

Diversity as represented by the Hill numbers was significantly different between APEIs $\left[\mathrm{N}_{0}\right.$ : ANOVA $F(2,10)=12.1, p<0.01$; $\mathrm{N}_{1}: F(2,10)=22.1, p<0.001 ; \mathrm{N}_{2}: F(2,10)=27.5, p<0.0001$; Table 3]. For all Hill numbers, APEI-7 was significantly lower than APEIs- 1 and 4 (all $p<0.05$; Tukey's HSD). Rarefied morphotype richness $\left(\mathrm{EM}_{65}\right)$ was also significantly different between APEIs $[F(2,10)=9.6, p<0.01]$, driven by significantly higher richness in the areas studied at APEI-1 than at APEI-7 $(p<0.01$; Tukey's HSD).

\section{Assemblage Composition}

The metazoan invertebrate assemblage was dominated by cnidarians (42\% of individuals) and echinoderms $(22 \%)$ in the study area at APEI-1 (Figure 6 and Table 4), and by poriferans (35\% and $50 \%$ of individuals) at APEIs 4 and 7 , with the next phylum being cnidarians (32\%) and annelids (13\%), respectively.
The metazoan invertebrate composition by density was significantly different between the APEI study areas (Figure 7; ANOSIM $R=1, p<0.001)$. Morphotypes contributing most to the dissimilarity between APEIs 1 and 4 were Umbellula sp. (PEN003) (8\%) and unclassifiable Porifera (POR000) (6\%), between APEIs 4 and 7 were Umbellula sp. (PEN003) (11\%) and Echiura (ANN020) (8\%) and, and between APEIs 1 and 7 were Echiura (ANN020) (6\%) and an actiniarian (ACT022) (5\%).

\section{Individual Body Size}

Individual body size of a sponge, Docosaccus sp. (HEX015), was significantly different between APEIs [ANOVA $F(2,18)=5.9$, $p<0.05$; Supplementary Material 4]. TukeyHSD post hoc test indicated that body size was significantly greater at APEI-1 than 7. Individual body size of an antipatharian, Abyssopathes lyra (ANT002), was significantly greater at APEI-1 than at APEI-4 $[F(1,16)=6.8, p<0.05]$. The individual body sizes of other morphotypes were not significantly different between sites.

\section{Echinoderms}

The density of echinoderms was significantly different between the APEI study areas [ANOVA $F(2,10)=21.9, p<0.001$; Table 3], with the density at APEI-7 study site significantly lower than at APEIs 1 and 4 (both $p<0.01$; TukeyHSD). Echinoderm biomass was not significantly different between APEIs, but mean echinoderm biomass at APEI-4 was approximately twice that of the other APEIs.

A total of 47 echinoderm morphotypes were observed on the abyssal plain. The number of morphotypes observed was significantly different between APEIs [ANOVA $F(2,10)=11.48$, $p<0.01$ ], with the number at APEI-7 being significantly lower from the other APEIs (both $p<0.01$; TukeyHSD). Two echinoderm morphotypes were shared between all APEIs (Galatheathuria sp. HOL038 and Unclassified holothurians HOL000), while 8 were unique to APEI-1, 13 were unique to APEI-4, and 5 were unique to APEI-7. Holothurians dominated the echinoderms observed at the abyssal plain sites (Figure 6 and Table 4), contributing 39\% to echinoderm density, across 21 morphotypes, approximately double the density of the next most common group (echinoids).

The echinoderm assemblage composition by density was significantly different between the APEIs (ANOSIM $R=0.84$, 


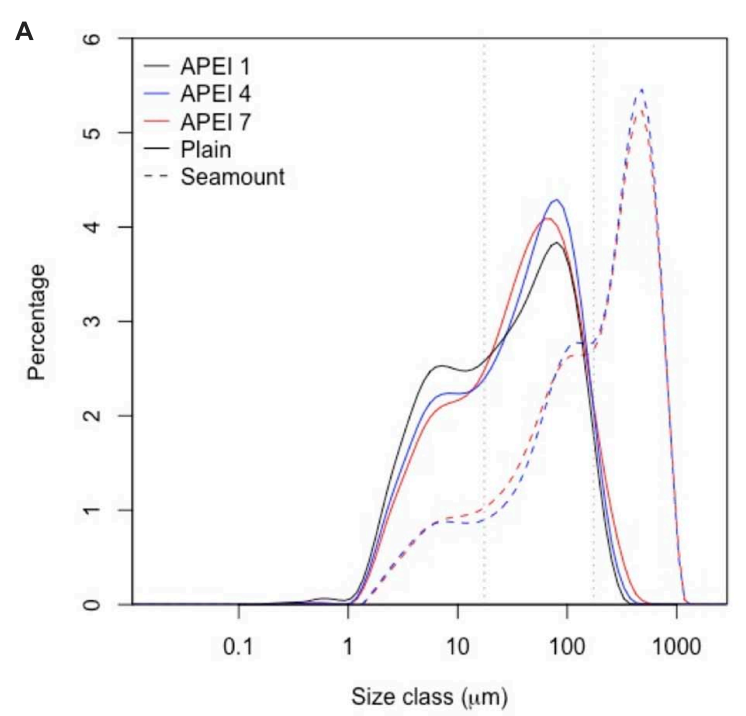

B

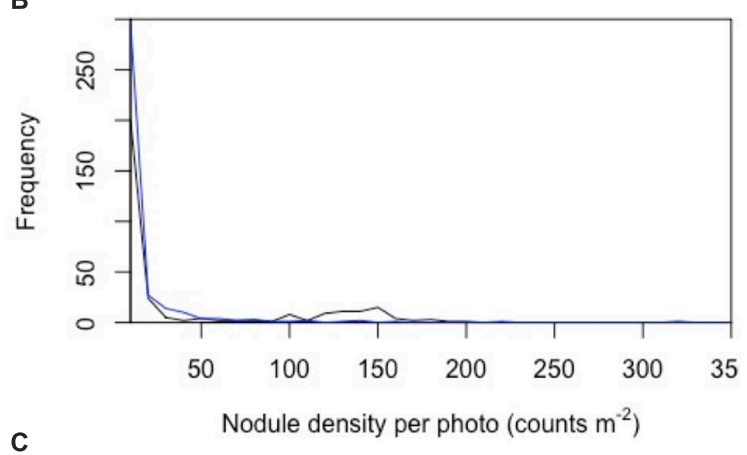

C

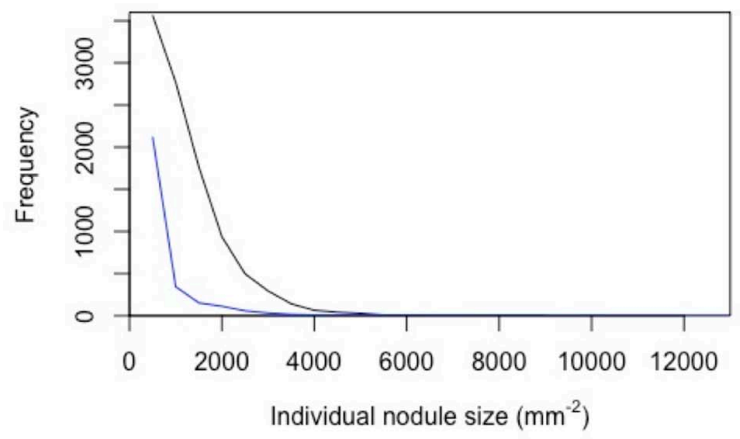

FIGURE 4 | Distributions of particle and nodule parameters at the study sites in the three APEls in the western CCZ. (A) Particle size distributions in sediments collected in cores ( $0-5 \mathrm{~cm}$ horizon) on the plain and seamounts. Grey dotted lines indicate size divisions between fine, intermediate and coarse particles (17.5 and $174 \mu \mathrm{m})$. (B,C) Distribution of nodule density (per image) and nodule size in APEls 1 and 4 .

$p<0.001$; Figure 7). Morphotypes contributing most to the dissimilarity between APEIs 1 and 4 were Kamptosoma sp. URC013 (14\%) and Unclassified holothurians HOL000 (8\%), between APEIs 4 and 7 were Kamptosoma sp. URC013 (17\%) and Synallactidae HOL007 (9\%), and between APEIs 1 and 7 were Asteroid AST004 (10\%) and Synallactidae HOL007 (8\%). The echinoderm assemblage composition by biomass was also significantly different between the APEIs (ANOSIM $R=0.43, p<0.01)$. Morphotypes contributing most to this dissimilarity between the APEIs were all large holothurians, with Galatheathuria sp. HOL 038 contributing significantly in all comparisons. Differences in assemblage by biomass between APEIs 1 and 4 were principally driven by Psychropotes cf $d y$ scrita HOL 047 (SIMPER 37\%) and Galatheathuria sp. HOL 038 (15\%), differences between APEIs 4 and 7 driven by P. dyscrita HOL 047 (34\%) and Galatheathuria sp. HOL 038 (26\%), and differences between APEIs 1 and 7 driven by Galatheathuria sp. HOL 038 (26\%) and Benthodytes sp. HOL 042 (21\%).

\section{Porifera}

The density of sponges was significantly different between APEIs [ANOVA $F(2,10)=26.9, p<0.0001]$. The lowest density of sponges was observed at APEI-1, where it was less than half the densities observed at APEIs 4 and 7.

The number of sponge morphotypes observed was significantly different between APEIs $[F(2,10)=4.2, p<0.05]$, with the highest number observed at APEI-7. A total of 29 sponge morphotypes were observed at the abyssal plain sites, with 9 morphotypes being common to all three APEIs (Cladorhiza sp. DES010, Hyalonema sp. HEX002, Hyalonema sp. HEX003, Placopegma sp. HEX005, Euplectellinae HEX014, Docosaccus sp. HEX015, Euplectella sp. HEX019, Acanthascus sp. HEX029, Unclassified poriferans POR000). Six unique morphotypes were observed at APEI-1, one at APEI-4 and 7 at APEI-7.

The sponge assemblage composition by density differed significantly between APEIs (ANOSIM $R=0.65, p<0.001$; Figure 7). Morphotypes contribution most to dissimilarity between APEIS 1 and 4 were Unclassified poriferans POR000 (SIMPER 24\%) and Hyalonema sp. POR002 (SIMPER 18\%), between APEIs 4 and 7 were Unclassified poriferans POR000 (13\%) and Docosaccus sp. HEX015 (13\%), and between APEIs 1 and 7 were Unclassified poriferans POR000 (20\%) and Hyalonema sp. POR002 (16\%).

\section{Cnidaria}

The density of cnidarians was significantly different between APEIs [ANOVA $F(2,10)=42.3, p<0.0001$ ], and was highest in APEI-1 and lowest in APEI-7.

A total of 37 cnidarian morphotypes were observed on the abyssal plain, with only 6 morphotypes observed at all three sites (Actiniaria ACT009; Actiniaria ACT022; Ceriantharia CER002; Ceriantharia CER005; Umbellula sp. PEN003; and Unclassified actiniarians ACT000). Ten morphotypes were unique to APEI1, five to APEI-4 and one to APEI-7. The number of cnidarian morphotypes observed was significantly different between APEIs [ANOVA $F(2,10)=65.8, p<0.0001]$, with the number of morphotypes at APEI-7 significantly lower than at the other two APEIs (both $p<0.0001$ ) by about threefold, and a significant increase in the number of morphotypes at APEI1 from APEI-4 ( $p<0.05)$. Actiniairians comprised 45\% of cnidarian abundance at the sites on the abyssal plain, across 13 morphotypes, more than double the abundance of the other groups. 


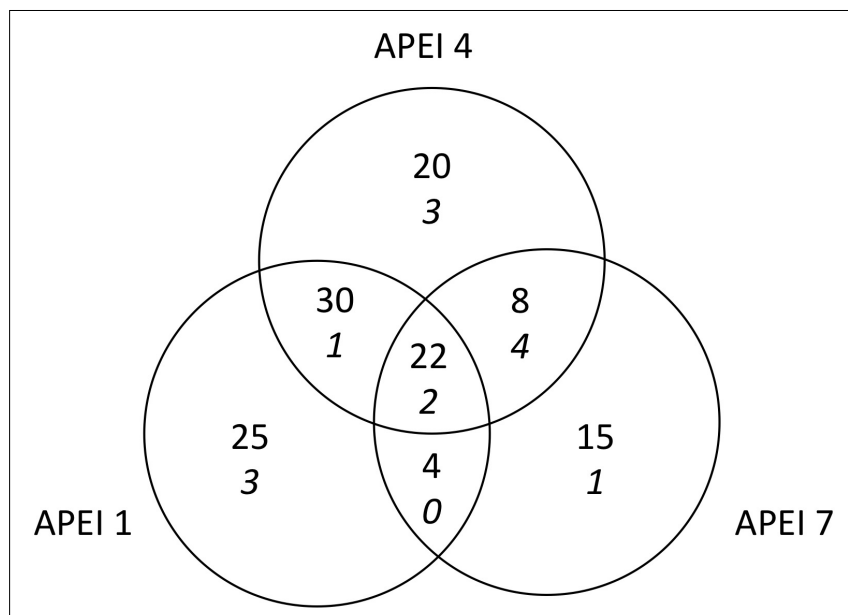

FIGURE 5 | Shared megafaunal morphotypes between APEls on the abyssal plain for both invertebrates (plain font) and highly mobile scavengers and predators (italics).

The cnidarian assemblage composition by density differed significantly between APEIs (ANOSIM $R=0.93, p<0.001$; Figure 7). Morphotypes contributing most to the dissimilarity between APEIs 1 and 4 were Umbellula sp. PEN003 (SIMPER 19\%) and Actiniarian ACT022 (13\%), between APEIs 4 and 7 were Umbellula sp. PEN003 (31\%) and Abyssopathes lyra ANT002 (8\%), and between APEIs 1 and 7 were Actiniarian ACT022 (13\%) and Unclassified Alcyonaria ALC000 (10\%).

\section{Xenophyophores}

Xenophyophores dominated the benthic megafaunal assemblage; densities of xenophyophores on the abyssal plains were two orders of magnitude greater than the densities of invertebrate megafauna (Table 3 and Figure 6). Densities of xenophyophores were significantly different between APEIs $[F(2,10)=1876.3$, $p<0.001]$. The magnitude of difference between APEIs was much greater than in the densities of invertebrate megafauna; densities of xenophyophores at APEI-4 were 1.8 times those at APEI-1 and 5.5 times those at APEI-7. The size of xenophyophore tests ("specimens") on the abyssal plain was significantly different between the APEIs $[F(2$, $2889)=10.1, p<0.001)$, driven by specimens at APEI4 being larger than specimens at the other two APEIs $(p<0.05)$.

\section{Highly Mobile Scavengers and Predators}

The total density of highly mobile scavengers/predators differed significantly between the APEIs $[F(2,10)=6.0, p<0.05$; Table 3], driven by $50 \%$ lower densities at APEI- 1 than at APEI-7 (TukeyHSD $p<0.05$ ). The density at APEI-4 was an intermediate value, and not significantly different from those at APEIs 1 or 7 . Diversity was not significantly different between APEIs (ANOVA for all Hill numbers $p>0.05$ ). A total of 14 morphotypes were found across the abyssal plain sites, with only two morphotypes (Aristeidae sp. DEC003 and unclassified fish OST000) common to all APEIs (Figure 5).

\section{Seamounts}

\section{Metazoan Invertebrates}

Density

Invertebrate megafaunal densities were substantially different between the two seamounts (Table 3). At APEI-4, the density on the seamount was within the range of densities found on the abyssal plain sites generally but less than on the plain in APEI-4. The density on the seamount at APEI-7 was approximately 4 times that observed on the seamount at APEI-4.

\section{Diversity}

The diversity of invertebrate megafauna in the study areas on the seamounts was generally lower than in those on the abyssal plain (Table 3). The number of morphotypes on the seamount at APEI-7 was double that found on the seamount at APEI-4, and more similar to the lowest value found on the plain (also at APEI-7). The Hill numbers and rarefied number of morphotypes were both substantially smaller on the seamounts than on the plain, and were slightly higher at the APEI-4 seamount than at the APEI7 seamount.

A total of 28 morphotypes of invertebrate megafauna were observed on the seamounts (Figure 3). Of these, $61 \%$ were only found on the seamounts, while 11 were also found on the plain. A total of 6 were common to both seamounts. Each seamount shared four morphotypes with the adjacent abyssal plain. Only two morphotypes were common to both seamounts and all abyssal plain sites. The metazoan invertebrate assemblage on the seamounts were dominated by cnidarians ( $83 \%$ of individuals at APEI-4 and 78\% at APEI-7; Figure 6), with echinoderms being the second largest major taxonomic group (15\% of individuals at APEI-4 and 20\% at APEI-7).

\section{Individual Body Size}

Individual body size of a cerianthid CER001, was significantly larger at the seamount at APEI-7 than at APEI-4 [ANOVA $F(1$, $28)=6.8, p<0.05$; Supplementary Material 4]. The individual body sizes of other morphotypes were not significantly different between seamounts.

\section{Echinoderms}

The density of echinoderms on the seamount at APEI-4 was within the range found at the abyssal plain sites, though half that found on the abyssal plain at APEI-4 (Table 3). However, the density of echinoderms on the seamount at APEI-7 was very high, about six times that found at the seamount at APEI-4 and an order of magnitude higher than on the adjacent plain. Echinoderm biomass at APEI-4 was within the range found at the abyssal plain sites, but lower than the biomass found on the abyssal plain at APEI-4. By contrast, echinoderm biomass at APEI-7 was approximately 5 times that found on the adjacent abyssal plain, and more than double the maximum echinoderm biomass found at the plain sites.

The number of echinoderm morphotypes found on the seamounts was within the range of numbers of morphotypes found on the abyssal plain. At APEI-4, the number of echinoderm morphotypes found on the seamount was less than one third 
TABLE 3 | Megafaunal community metrics by APEl and habitat type expressed as means [95\% confidence interval of the mean] determined in photographic sample units: density, univariate diversity metrics (Hill numbers $\mathrm{N}_{0}$ [number of morphotypes], $\mathrm{N}_{1}$ [Shannon index] and $\mathrm{N}_{2}$ [Simpson's index]; expected number of morphotypes rarefied to 65 specimens, $\mathrm{EM}_{65}$ ), fresh wet weight biomass of echinoderms.

\begin{tabular}{|c|c|c|c|c|c|}
\hline \multirow[b]{2}{*}{ Location } & \multicolumn{3}{|c|}{ Abyssal plain } & \multicolumn{2}{|c|}{ Seamount } \\
\hline & APEI-1 & APEI-4 & APEI-7 & APEI-4 & APEI-7 \\
\hline \multicolumn{6}{|c|}{ Metazoan invertebrates } \\
\hline Density (ind $\mathrm{m}^{-2}$ ) & $0.058[0.053,0.063]$ & $0.059[0.053,0.065]$ & $0.042[0.038,0.046]$ & 0.049 & 0.216 \\
\hline $\mathrm{N}_{0}$ & $43.0[40.9,45.1]$ & $38.6[33.0,44.3]$ & $26.3[21.4,31.1]$ & 11 & 23 \\
\hline $\mathrm{EM}_{65}$ & $33.8[32.8,34.7]$ & $29.9[27.1,32.7]$ & $24.9[21.3,28.5]$ & 10.9 & 9.7 \\
\hline \multicolumn{6}{|l|}{ Echinoderms } \\
\hline Density (ind $\mathrm{m}^{-2}$ ) & $0.013[0.011,0.014]$ & $0.015[0.013,0.017]$ & $0.004[0.001,0.007]$ & 0.007 & 0.043 \\
\hline $\mathrm{N}_{0}$ & $12.8[11.3,14.2]$ & $13.2[10.1,16.3]$ & $4.8[1.9,7.6]$ & 4 & 9 \\
\hline Biomass (gwet $\mathrm{m}^{-2}$ ) & $0.87[0.41,1.34]$ & $2.04[0.55,3.53]$ & $0.99[0.23,1.75]$ & 1.79 & 4.90 \\
\hline Density (ind $\mathrm{m}^{-2}$ ) & $0.025[0.023,0.027]$ & $0.019[0.017,0.022]$ & $0.006[0.002,0.009]$ & 0.041 & 0.170 \\
\hline $\mathrm{N}_{0}$ & $17.0[17.0,17.0]$ & $14.0[12.4,15.6]$ & $5.0[3.2,6.8]$ & 6 & 12 \\
\hline \multicolumn{6}{|l|}{ Xenophyophores } \\
\hline Density (ind $\mathrm{m}^{-2}$ ) & $2.065[1.967,2.163]$ & $3.734[3.644,3.824]$ & $0.680[0.655,0.706]$ & 0.128 & 0.034 \\
\hline \multicolumn{6}{|c|}{ Highly mobile scavengers and predators } \\
\hline Density (ind $\mathrm{m}^{-2}$ ) & $0.0013[0.0010,0.0016]$ & $0.0020[0.0015,0.0024]$ & $0.0028[0.0019,0.0037]$ & 0.0037 & 0.0040 \\
\hline $\mathrm{N}_{0}$ & $2.3[1.8,2.7]$ & $3.0[2.1,3.9]$ & $3.0[1.6,4.4]$ & 3.0 & 2.0 \\
\hline
\end{tabular}

The numbers and sizes of photographic sample units are given in Table 1.

of the number found on the abyssal plain, while at APEI-7, the number of morphotypes observed on the seamount was almost double that found on the adjacent abyssal plain. In contrast to the abyssal plain sites, holothurians contributed only $25 \%$ to echinoderm density at the seamount sites, in 4 morphotypes, while ophiuroids contributed $67 \%$ to density, almost entirely in a single morphotype (OPH 012).

Ophiuroidea OPH012 and Laetmogone sp. HOL030 were the two morphotypes found in the highest densities at both seamount sites (Figure 6). The density of Ophiuroid 012 at the seamount at APEI-7 was particularly high $\left(0.030\right.$ ind $\left.\mathrm{m}^{-2}\right), 4.4$ times the density of the second-ranked Laetmogone sp. $\left(0.007\right.$ ind $\left.\mathrm{m}^{-2}\right)$; the most common morphotype at the APEI-4 seamount occurred at lower densities than these $\left(0.004\right.$ ind $\left.\mathrm{m}^{-2}\right)$. Laetmogone sp. was the highest-ranked morphotype in terms of biomass at both seamounts, contributing $99 \%$ of biomass at APEI-4 and $53 \%$ at APEI-7.

The echinoderm assemblage structures (by density and biomass) on the seamounts appear to be more similar to each other than to the corresponding adjacent abyssal plain (Figure 7).

\section{Porifera}

No porifera were observed in the soft sedimented environment on the seamounts.

\section{Cnidaria}

The density of cnidarians on the seamounts was greater than on the respective adjacent abyssal plain; at APEI4 the density on the seamount was double that on the plain, while at APEI-7 it was 28 times that observed on the plain. The density of cnidarians was much greater than that of echinoderms on the seamounts, while only slightly greater on the plains.

The number of cnidarian morphotypes found at each of the two seamount sites was within the range found at the sites on the abyssal plain (Table 3 ). The observed morphotype richness at the APEI-7 seamount site was double the number found at the APEI- 4 seamount site. A total of 15 cnidarian morphotypes were found on the seamounts, with seven also found on the abyssal plain. Only three cnidarian morphotypes were common to both seamounts. At APEI-4, three morphotypes were found on both the seamount and abyssal plain, while 8 were common to both habitats in APEI-7. In contrast to the abyssal plain, where the dominant actinians were accompanied by much smaller densities of alcyonacea and antipatharia, one seamount assemblage was dominated by alcyonaceans and at the other cerianthids contributed highly to cnidarian and invertebrate density.

As found for echinoderms, the cnidarian assemblage structures by density on the seamounts appear to be more similar 


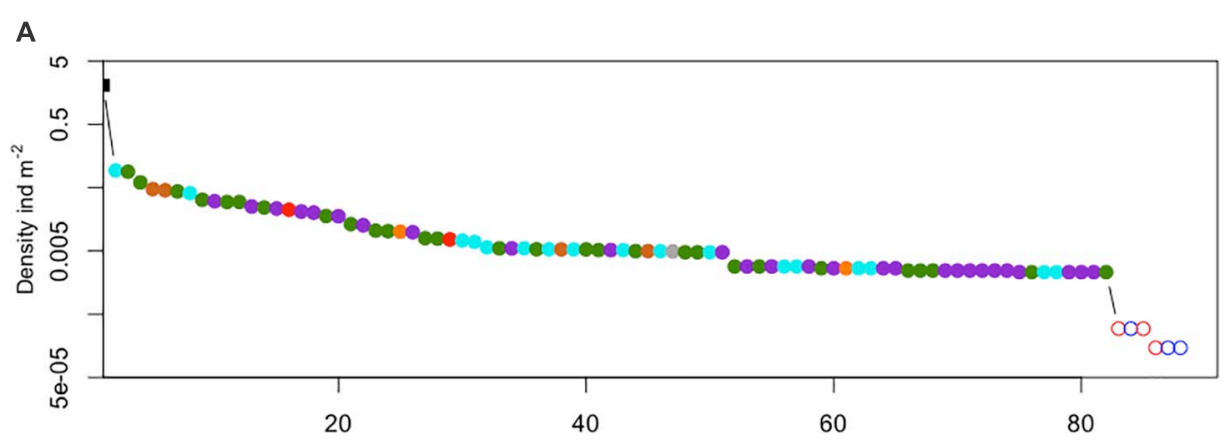

B

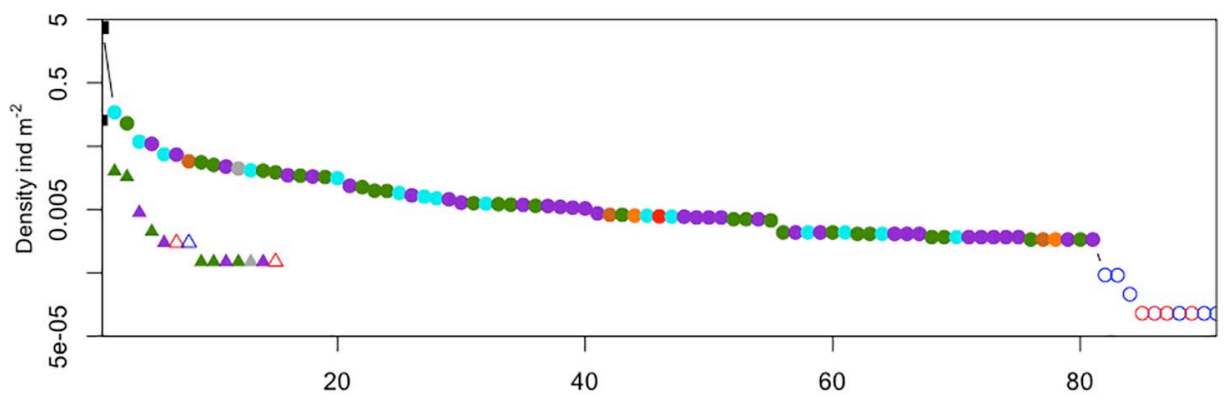

C

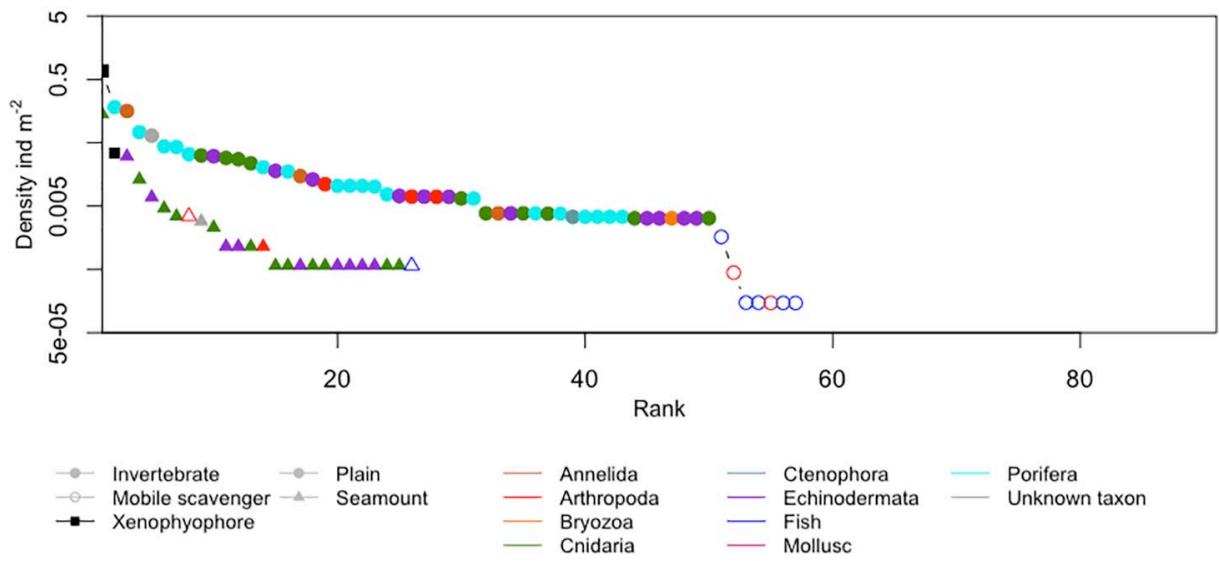

FIGURE 6 | Ranked densities of all seabed megafaunal morphotypes (metazoan invertebrates, highly mobile scavengers/predators, and xenophyophores) observed at (A) APEI-1, (B) APEI-4, and (C) APEI-7. Note the log scale in the $y$-axis.

to each other than to the corresponding adjacent abyssal plain (Figure 7).

\section{Summary}

Megafaunal communities in the soft sedimented environments on the seamounts were different from those on the abyssal plain. Invertebrate megafaunal densities were comparable or higher, and diversity was lower on the seamounts than on the plains, and most morphotypes found on the seamounts were unique to that environment. The density of cnidarians was higher on the seamounts than on the plains; in contrast, no porifera were found on the seamounts.

The megafaunal communities on the two seamounts differed from one another. Invertebrate megafaunal density and diversity were lower at APEI-4 than APEI-7. Echinoderm density, diversity and biomass, and cnidarian density and diversity were greater on the seamount at APEI-7.

\section{Xenophyophores}

The density of xenophyophores was substantially lower on the seamounts than on the abyssal plain, 29 times smaller at APEI4 and 22 times smaller at APEI-7 (Table 3). There was also substantial difference between the seamounts, with the density of xenophyophores on the seamount at APEI-4 being 3.7 times that at APEI-7. However, xenophyophores were still important to the megabenthic assemblages on the seamounts (Figure 6). At APEI-4, the density of xenophyophores was greater than 
TABLE 4 | Contributions of major taxonomic groups to the metazoan invertebrate assemblage at the study sites: mean percentage of metazoan invertebrate density (\%) and morphotype richness $\left(\mathrm{N}_{0}\right)$ over all sample units.

\begin{tabular}{|c|c|c|c|c|c|c|c|c|c|c|c|}
\hline \multirow[t]{3}{*}{ Phylum } & \multirow[t]{3}{*}{ Class or order } & \multicolumn{6}{|c|}{ Abyssal plain } & \multicolumn{4}{|c|}{ Seamount } \\
\hline & & \multicolumn{2}{|c|}{ APEI-1 } & \multicolumn{2}{|c|}{ APEI-4 } & \multicolumn{2}{|c|}{ APEI-7 } & \multicolumn{2}{|c|}{ APEI-4 } & \multicolumn{2}{|c|}{ APEI-7 } \\
\hline & & $\%$ & $N_{0}$ & $\%$ & $N_{0}$ & $\%$ & $N_{0}$ & $\%$ & $N_{0}$ & $\%$ & $N_{0}$ \\
\hline \multirow[t]{5}{*}{ Echinodermata } & Asteroidea & 1 & 4 & 1 & 2 & 5 & 4 & 0 & 0 & 1 & 3 \\
\hline & Crinoidea & 3 & 4 & 6 & 9 & 0 & 0 & 0 & 0 & 0.2 & 1 \\
\hline & Echinoidea & 5 & 4 & 6 & 4 & 0 & 0 & 2 & 1 & 0 & 0 \\
\hline & Holothuroidea & 8 & 10 & 9 & 15 & 5 & 6 & 9 & 1 & 4 & 4 \\
\hline & Ophiuroidea & 5 & 5 & 3 & 4 & 0.3 & 1 & 5 & 2 & 14 & 1 \\
\hline Total & & 22 & 27 & 25 & 34 & 10 & 11 & 16 & 4 & 19 & 9 \\
\hline \multirow[t]{6}{*}{ Cnidaria } & Actiniaria & 26 & 11 & 7 & 7 & 9 & 5 & 45 & 2 & 8 & 3 \\
\hline & Alcyonacea & 12 & 8 & 4 & 7 & 0 & 0 & 2 & 1 & 66 & 2 \\
\hline & Antipatharia & 2 & 3 & 6 & 6 & 0.3 & 1 & 0 & 0 & 0 & 0 \\
\hline & Ceriantharia & 1 & 3 & 1 & 2 & 3 & 3 & 35 & 2 & 4 & 5 \\
\hline & Corallimorpharia & 0.2 & 1 & 2 & 1 & 0 & 0 & 0 & 0 & 0 & 0 \\
\hline & Pennatulacea & 0.8 & 1 & 12 & 3 & 0.3 & 1 & 2 & 1 & 0.5 & 2 \\
\hline Total & & 42 & 27 & 32 & 26 & 13 & 10 & 82 & 6 & 79 & 12 \\
\hline \multirow[t]{3}{*}{ Porifera } & Desmospongiae & 2 & 4 & 1 & 2 & 0.3 & 1 & 0 & 0 & 0 & 0 \\
\hline & Hexactinellida & 8 & 11 & 10 & 9 & 20 & 12 & 0 & 0 & 0 & 0 \\
\hline & Unclassified porifera & 9 & 2 & 24 & 5 & 30 & 7 & 0 & 0 & 0 & 0 \\
\hline Total & & 19 & 17 & 35 & 16 & 50 & 20 & 0 & 0 & 0 & 0 \\
\hline
\end{tabular}

that of invertebrate megafauna (2.6 times), while at APEI-7, xenophyophores were the second ranked morphotype in terms of density (Figure 6). Test sizes were significantly smaller on the seamounts than on the plain $[F(1,78)=6.3, p<0.05]$, but were not different between seamounts.

\section{Highly Mobile Scavengers and Predators}

Highly mobile scavengers and predators were observed in greater densities on the seamounts than on the plain. Only the morphotype unclassified Arthropoda (ART000) was common to both seamounts and the abyssal plain.

\section{DISCUSSION}

\section{Environmental Drivers of Megafaunal Assemblages on the Abyssal Plains of the Western CCZ}

We found low density, high diversity benthic megafaunal communities on the abyssal plains of the western CCZ, with significant differences between the study areas in the three APEIs in both the megafaunal communities and habitat. These community differences were observed in terms of density, diversity and assemblage composition, with few common morphotypes between sites and many rare morphotypes observed only once. Metazoan invertebrate density and diversity were lower to the southeast, at APEI-7, where estimated POC flux was highest, sediments were finest and no nodules were observed. Conversely, metazoan invertebrate density and diversity were higher at APEIs-1 and 4 to the northwest, where nodules were observed on the coarser sediment, and POC flux was estimated to be lower. These environmental factors (nodule abundance, sediment texture, POC flux) are likely to have impacted the observed megafaunal density, diversity and assemblage composition, both directly and in combination.

\section{Nodule Occurrence and Sediment Characteristics as Drivers of Metazoan Megafaunal Assemblages}

Nodules are an important source of habitat heterogeneity on abyssal plains, and exert a major influence on megafaunal assemblages across the CCZ. At the western CCZ study sites, there was a $40 \%$ increase in density and an increase of 30 morphotypes at the study sites with nodules compared to the site without (Table 3 ). At a local scale, nodule presence has been observed to increase densities twofold, with nodules harbouring specific megafauna, such as antipatharians and alcyonaceans, while some fauna have been observed only in nodule-free areas (Amon et al., 2016; Vanreusel et al., 2016; Simon-Lledó et al., 2019b). Metazoan and foraminiferal densities have been observed to increase substantially, and metazoan assemblage composition to vary, with nodule cover at low nodule coverage ( 1-3\%; Simon-Lledó et al., 2019b). Similarly, metazoan diversity was higher at lower nodule densities ( $<15 \%$ seabed cover; Amon et al., 2016) than at higher nodule densities. These community-level variations were a result of changes in the densities of both mobile and nonmobile taxa. The low nodule coverages are comparable to those found at the study sites in APEIs 1 and 4, suggesting that the presence or absence of nodules may have influenced the assemblages observed there. Since nodule cover was 


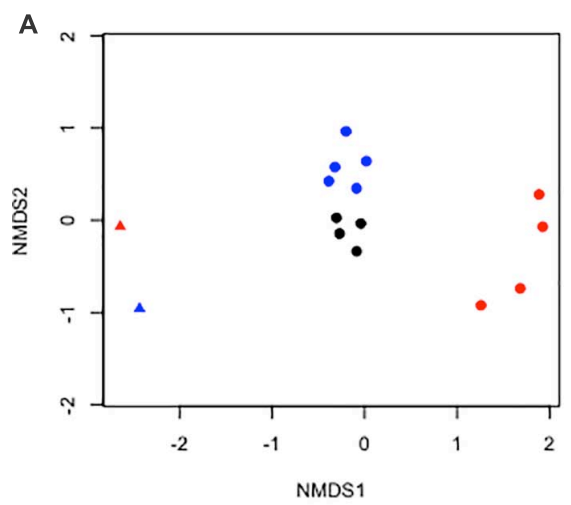

B

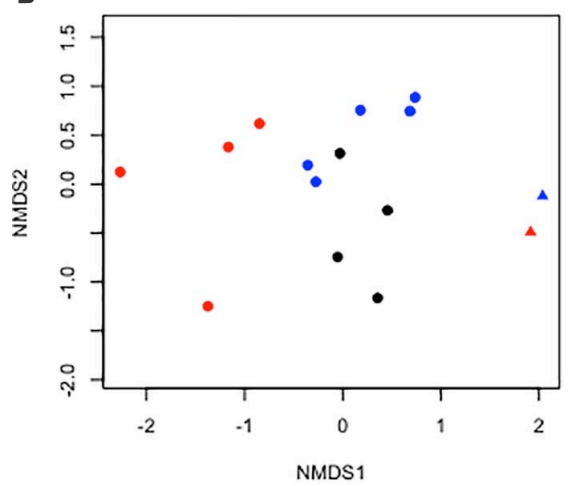

C

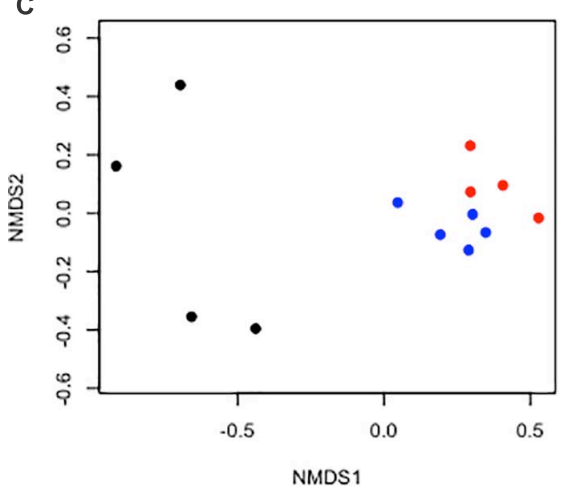

D

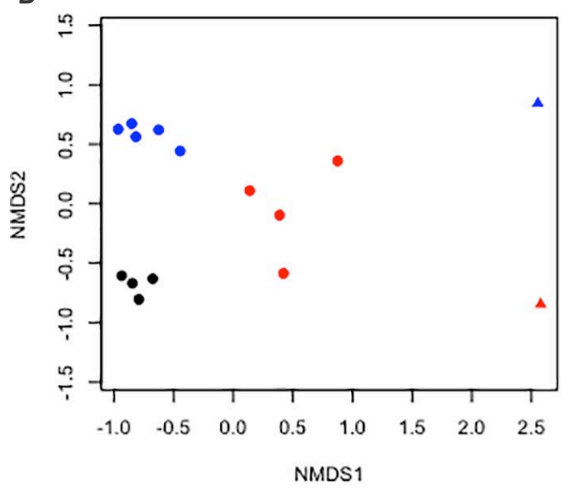

FIGURE 7 | Two-dimensional non-metric multidimensional scaling ordination plots of community composition similarity for echinoderm (A) density and (B) biomass (fresh wet weight), (C) poriferan density, and (D) cnidarian density on the abyssal plain (circles) and seamounts (triangles) in the APEls ( $1=$ black, 4 = blue, 7 = red symbols). patchy at these two study sites (Figure 3), the megafauna observed likely include a combination of morphotypes suited to both nodules and nodule-free areas. These habitat niches are favoured by different taxa, leading to switches in major groups dominant in areas with contrasting nodule presence. For example, while densities of holothurians and (largely noduleattaching) actiniarians at the high nodule density APEI-1 site were double and triple those observed at the nodule-free APEI-7 study site, densities of (largely non-nodule attaching) hexactinellids and sponges of indeterminate class were halved (Table 4). Docossacus sp., a plate-shaped glass sponge that is supported on soft sediments by spicules (Kahn et al., 2020), contributed significantly to the high density of hexactinellids at APEI-7. The preference of some taxa for the presence or absence of nodules (latter for hexactinellids) at these sites were confirmed through the analysis of environmental DNA (Laroche et al., 2020). Thus, the habitat heterogeneity provided by the patchy abundance of nodules at APEIs 1 and 4 is likely a substantial driver of variation in the megafaunal communities in the western CCZ.

Nodule-related seabed heterogeneity is accompanied by differences in the soft sediment particle size, which likely also influences the megabenthic assemblage. Taxa that interact with the sediment, such as deposit feeding and burrowing fauna, are sensitive to its granulometric characteristics (Hudson et al., 2005). Nodule-free areas were observed at all three APEIs (Figure 3), and few soft-sediment interacting taxa were common to all sites (though the lack of overlapping morphotypes may be related to the small sample size). However, these contributed only a small proportion of all morphotypes observed at the nodule-free APEI-7 study site. Morphotypes that interact with soft sediments (e.g., holothurians, annelids, some asteroids) were observed at all abyssal plain study sites, but the morphotypes present and their densities both varied. Densities of echiurans (ANN020), deposit feeding burrowing annelids that leave large feeding traces on the sediment surface (Bett and Rice, 1993), were highest at APEI7, with 3.5- and 5.4-fold higher densities than in APEIs 1 and 4, respectively. Differences in densities and observed morphotypes may be related to differences in sediment particle size distributions between the sites (Figure 3), with the APEI-7 having the coarsest sediment. Similar relationships between soft-sediment adapted megafaunal morphotypes and sediment texture have been observed with small changes to sediment texture at the nodule-free abyssal Porcupine Abyssal Plain in the Atlantic Ocean (Durden et al., 2020b). Other sediment conditions not measured at these sites, such as porosity and biogeochemical parameters (e.g., Volz et al., 2018), may also influence the assemblage in areas of soft sediments. Finally, the observed sediment particle size distribution is related to other environmental factors important to the faunal assemblage, including the near surface current regime, and deposition and bioturbation of organic material (Turnewitsch et al., 2015), which are influenced by seabed bathymetry. Even small changes in seabed water depth (12.5 $\mathrm{m})$, smaller than those in the study areas $(18-50 \mathrm{~m})$, can result in changes in sediment particle size, with corresponding alterations to megafaunal assemblage related to deposit feeders 
and burrowing organisms (Durden et al., 2020b). While the effects of sediment texture on megafaunal density and diversity may not be comparable to those of nodules (SimonLledó et al., 2019a), our results suggest that particle size may influence the presence and densities of morphotypes in the western CCZ.

\section{Organic Matter Flux as a Driver of Metazoan Megafaunal Assemblages}

The differences in the density and diversity of metazoan megafaunal assemblages between APEI study sites were also likely related to the differences in POC flux, a relationship previously observed in the equatorial Pacific and other abyssal areas (Smith et al., 1997). The largest difference in estimated annual POC flux was between the most distant APEIs, with estimated annual POC flux 73\% higher at APEI-7 than at APEI-1. The densities of highly mobile scavengers and predators, a group that can be equally surveyed regardless of nodule occurrence, paralleled estimated annual POC flux. This finding contrasts with a regional assessment that found no relationship between POC flux and fish density (though the conclusions of regional synthesis may be confounded by methodological differences of the studies involved) (Drazen et al., in review). In contrast to the pattern for mobile scavengers and predators, observed densities of metazoan invertebrates in this study were lower where POC flux was highest. The relationship between POC flux and megafaunal assemblages is likely complicated by the presence of nodules, as a link between low organic matter deposition and nodule abundance has been observed (Mewes et al., 2014). However, observations of this relationship from a nodule-free abyssal site provide an interesting comparison. Temporal variation in POC flux at the eastern Pacific abyssal time-series site Station M was linked to major alterations to the megafaunal community observed. The densities of suspension and filter feeders decreased while holothurian density increased in relation to an increase in POC flux of two orders of magnitude (0.07-7 $\left.\mathrm{gC} \mathrm{m}^{-2} \mathrm{y}^{-1}\right)$ (Kuhnz et al., 2014). This contrasts with our observations from the western CCZ, where higher densities of porifera (largely filter feeders) were found along with increased POC flux, though the range of POC flux was smaller in magnitude to that of Station M. These high densities of porifera in the western CCZ may be related to nodule presence for attachment, as suggested for the eastern CCZ (Vanreusel et al., 2016). However, the soft sedimentdwelling Docosaccus sp. contributed substantially to the relatively high hexactinellid density at APEI-7, where POC flux was highest. The high density of Docosaccus sp. was accompanied by smaller individual body sizes, in similarity to observations from Station $M$, where this sponge recruited quickly after increased POC flux, resulting in increased densities and small body sizes (Kahn et al., 2012; Kuhnz et al., 2014). The high sponge density observed at APEI-7 included only relatively low densities of carnivorous Desmospongiae $\left(0.00015\right.$ ind $\left.\mathrm{m}^{-2}\right)$, which were ten times more abundant and diverse at APEI-1 $\left(0.0012\right.$ ind $\mathrm{m}^{-2}$ ), where POC flux was lowest. The densities and diversity of these carnivorous sponges have been observed to increase as filter feeding sponges decline, both at Station
M (Kuhnz et al., 2014) and at other nodule fields in the Pacific with similar desmosponge densities (Maldonado et al., 2015). The increase in holothurian densities along with POC flux at Station M were driven by large changes to densities of small holothurians selecting fresh organic matter (e.g., Peniagone spp., Elpidia); similar morphotypes (e.g., Peniagone sp. HOL028, Deima sp. HOL018, Elpidiidae HOL020) were observed at APEI-7 but not at APEI-1. The high densities of echiurans at APEI-7 may also be related to their affinity for fresh organic matter (Durden et al., 2020a), in addition to soft sediment texture (above).

\section{The Abyssal Plains of the Western CCZ as Part of the Region}

Invertebrate megabenthic densities in the three APEIs in the western CCZ were low compared to other study locations in the central Pacific, without a straightforward relationship to POC flux. Two other studies provide east/west end members to our study locations, with an east-to-west increase in POC flux and megafaunal density between them: the Kiribati Area $\mathrm{C}$ to the west, where estimated POC flux $\left(1.5 \mathrm{gC} \mathrm{m}^{-2} \mathrm{y}^{-1}\right)$ was $125 \%$ and total density $\left(0.12\right.$ ind $\left.\mathrm{m}^{-2}\right)$ was $200 \%$ of those observed at APEI-1 (Simon-Lledó et al., 2019c); and a central equatorial Pacific site $\left(5^{\circ} \mathrm{N}, 140^{\circ} \mathrm{W}\right)$ to the east, where POC flux (1.9 $\mathrm{gC} \mathrm{m}^{-2} \mathrm{y}^{-1}$; Washburn et al., 2021a) was similar and density (0.18 ind $\mathrm{m}^{-2}$; Smith et al., 1997) was more than four times those at APEI-7. The lower POC flux and difference in megafaunal densities observed at APEIs- 1 and 4 may be related to latitude, as more labile organic matter has observed closer to the equator in the Pacific, where upwelling leads to much greater primary production (Smith et al., 1997). Both the Kiribati Area $\mathrm{C}$ and the central equatorial Pacific that bookend our study sites east-to-west are at $5^{\circ} \mathrm{N}$, similar to APEI-7, and also used photographic methods for estimating megafaunal densities. Thus, it appears that the relationship between estimated POC flux and metazoan densities across the area is not simple.

The observed megafaunal densities in the western APEIs were similar to or lower than those previously observed in the eastern CCZ. Metazoan megafaunal density in APEI-3 $\left(\sim 0.05\right.$ ind $\left.\mathrm{m}^{-2}\right)$ (Vanreusel et al., 2016) was similar to those observed in APEIs 1, 4 and 7. However, the APEI-3 densities are likely an underestimate, as organisms less than $30 \mathrm{~mm}$ in size were excluded based on image resolution. In contrast, observed megafaunal densities from the easternmost APEI-6 and eastern CCZ contract areas (BGR, GSR, IFREMER, IOM, TOML, UK-1 contract areas) were substantially higher than those found in the APEIs of the western CCZ: reported metazoan densities ranged from 0.11 to 1.5 ind $\mathrm{m}^{-2}$ (Amon et al., 2016; Vanreusel et al., 2016; Simon-Lledó et al., 2019a, 2020; Jones et al., in review), values that may also be underestimates because of similar exclusion of small organisms. Where values were reported, the locations with higher megafaunal densities than the western APEIs also had higher nodule abundance (134 $\mathrm{m}^{-2}$ in APEI-6) (Simon-Lledó et al., 2019a) or greater seabed nodule cover (13-37\% in TOML contract areas) 
(Simon-Lledó et al., 2020), and POC flux similar to or lower (0.5$1.6 \mathrm{gC} \mathrm{m}^{-2} \mathrm{y}^{-1}$ ) than those observed in the western APEIs. These comparisons suggest that environmental and the megafaunal density variations are substantial across the CCZ, and that the relationships between environmental factors and the megafaunal assemblage are complex.

These spatial variations in megafaunal densities across the CCZ may be substantially confounded by temporal variation. The temporal mismatch between studies, often with seasons and years separating observations (e.g., observations from 2013 in Amon et al., 2016; observations from 2018 in this study), makes differentiating spatial from temporal variations difficult. Metazoan megafaunal assemblages have been observed to vary with seasonal and interannual changes to organic matter inputs at other abyssal sites, with densities of some taxa changing by orders of magnitude over periods of 1-2 years (Billett et al., 2001, 2010; Kuhnz et al., 2014). Shorter-term factors altering behaviour of some abyssal organisms, such as movements in sponges that may impact their consistent identification in images, have only just been discovered (Kahn et al., 2020), and longer-term changes to megabenthic biomass and biodiversity are anticipated as a result of climate change (Smith et al., 2008; Jones et al., 2014; Levin et al., 2020).

Diversity of metazoan megafauna on the abyssal plain is high across the CCZ and central Pacific, as evidenced by the high numbers of morphotypes observed (e.g., 136 morphotypes at APEI-6, Simon-Lledó et al., 2019a; 145-189 invertebrate taxa at three TOML sites, Simon-Lledó et al., 2020; 126 morphotypes, this study). The combination of high diversity with low density results in substantial proportions of rare morphotypes. At APEI6 in the eastern CCZ, $40 \%$ of morphotypes were observed fewer than 3 times (Simon-Lledó et al., 2019a), while in the APEIs of the western CCZ, 27\% of morphotypes were observed only once. Although direct comparisons of betadiversity across the region using images is currently precluded by a lack of standardisation of taxonomic identifications and methodological differences including sampling effort, some studies using consistent methodologies have found few overlapping morphotypes between the multiple areas they examined. At the three sites near Kiribati, nearly half (49\%) of all morphotypes were detected only at a single location, with only $33 \%$ of morphotypes found across all study sites (Simon-Lledó et al., 2019c). Similarly, in the APEIs of the western CCZ, $48 \%$ of morphotypes were found only at one of the APEIs, and only $18 \%$ of morphotypes were found at all locations. In reviewing taxonomic identifications used in previous studies (see "Megafaunal Community Assessment"), approximately 100 of those observed in this study were not observed in those previous studies. However, the small seabed areas surveyed precludes robust assessments of endemicity from morphotype presence in photographs. Genetic techniques have been used to examine the connectivity of individual species, with connectivity between APEI- 6 and adjacent contract areas in the eastern CCZ found for a common demosponge (Taboada et al., 2018).

\section{Xenophyophores on the Abyssal Plains of the Western CCZ}

Despite the low densities of megafauna generally in the western CCZ, there was one highly abundant group: agglutinated monothalamous benthic foraminifera (xenophyophores). These giant protists dominated the megafauna at the abyssal plain sites, and were found in the highest densities and largest test sizes at APEI-4. Why this group was particularly successful at this site, characterised by intermediate depth, nodule cover and estimated POC flux, is difficult to assess. Although it was impractical to discriminate between morphotypes among all the specimens ( $>58,000$ were observed), the assemblages are clearly quite diverse. At least 22 morphotypes, some attached to nodules, were recognised in a subset of specimens from the abyssal plain sites (Gooday et al., 2020a). The lack of nodules observed at APEI-7 may result in a lower foraminiferal diversity at the site, similar to the nodule effect on metazoan invertebrates (Amon et al., 2016; Simon-Lledó et al., 2019b). Many of the morphotypes project well above the sediment surface and have morphologies that suggest suspension-feeding or particle trapping trophic strategies (Levin and Gooday, 1992; Gooday et al., 2020b). However, those that are flat-lying are more likely to feed directly on the sediment surface. The combination of species represented may also explain the differing sizes of specimens observed between sites, the large test sizes at APEI-4 possibly being related to a prevalent morphotype.

Although found in high densities and with large test size, the relatively small proportion of test volume occupied by cytoplasm means that megafaunal foraminifera are unlikely to contribute substantially to megafaunal biomass (Levin and Gooday, 1992; Gooday et al., 2018b, 2020a). Estimates were made using a hemisphere to represent the test volume (reasonable for those with reticulated and folded plate-like morphologies) and the method described by Gooday et al. (1993). Mean foraminiferal biomass was estimated at $2.2 \times 10^{-5} \mathrm{~g} \mathrm{~m}^{-2}$ on the abyssal plain in APEI- 1 and $4.6 \times 10^{-8} \mathrm{~g} \mathrm{~m}^{-2}$ at APEI-4, a tiny fraction of the observed echinoderm biomass at these sites (Table 3). Thus, this group may contribute substantially to biodiversity in the western CCZ, but their contributions to megafaunal biomass appears to be small in these areas.

Xenophyophores dominate the megafauna across much of the CCZ. High densities of these protists were observed from the west, in the Kiribati Area $\mathrm{C}\left(0.5\right.$ ind $\left.\mathrm{m}^{-2}\right)$ (Simon-Lledó et al., 2019c), to the extreme east of the CCZ, in APEI-6 (2 ind $\left.\mathrm{m}^{-2}\right)$, with lower absolute densities reported in the Russian contract area $\left(0.16\right.$ ind $\left.\mathrm{m}^{-2}\right)$ (Kamenskaya et al., 2013) and UK-1 contract area (0.08-0.16 ind $\mathrm{m}^{-2}$ ) (Amon et al., 2016). The diversity of xenophyophores is often difficult to estimate from seafloor imagery, partly due to the morphological variability of some morphotypes and genetic evidence that morphologically similar specimens may encompass several distinct species (Gooday et al., 2018a). Nevertheless, observations in APEIs 1, 4 and 7 have contributed substantially to the number of observed morphotypes across the CCZ (Gooday et al., 2020a,b). At least one species, Aschemonella monilis, has been observed at multiple locations including APEI-4 east to UK-1 contract 
area. Morphotype diversity is discussed in more detail in Gooday et al. (2020a).

\section{Seamount Communities in the Western CCZ}

The seabed environment at the soft sedimented study areas on the seamounts in APEIs 4 and 7 differ substantially from those found on the adjacent abyssal plain. The white sediments, rich in planktonic foraminiferan shells, are characteristic of many Pacific seamount summits above the carbonate compensation depth (Smith and Demopoulos, 2003). This depth is approximately $4,500 \mathrm{~m}$ across the CCZ, but is likely deeper to the west (Mewes et al., 2014). Sediments at these two seamount sites appeared similar in terms of composition and particle size (Table 2 and Supplementary Material 3), but differed from the thin coccolithophore-rich sediment observed at seamount in APEI6 (Jones et al., in review). Although the seamount study sites in APEIs 4 and 7 are located at low latitudes, the depth of their summits suggest that they likely do not benefit from surface chlorophyll enhancements (Leitner et al., 2020b), but organic matter may be enhanced by resuspension and increased horizontal flux. These alterations to the seabed environment likely influence the megafaunal communities observed.

Differences in the seabed environments between the two seamounts likely influence the differences in the observed megafaunal densities. The relatively high density (approximately fourfold) and diversity (double the morphotype richness) of metazoan invertebrates observed at the seamount in APEI-7 in comparison to the seamount in APEI-4 is echoed in the density (approximately four times greater) and diversity (double richness) of Cnidaria, and Echinoderm density (approximately six times greater). These differences are likely related to the differences in the mean seabed depths of the surveyed areas, where the APEI-7 seamount is substantially shallower, but also the range of seabed depths surveyed, which was 5 times greater at APEI-7. Such depth differences likely influence megafaunal communities, as observed for relatively small topographic features on the plains (Durden et al., 2015, 2020b; Simon-Lledó et al., 2019a, 2020), with significant differences in megafaunal communities related to species replacement at elevation differences of only $12.5 \mathrm{~m}$ (Durden et al., 2020b). The differences in the depth ranges of seabed observations at each seamount has been highlighted as a limitation to comparability between seamounts in the eastern CCZ (Cuvelier et al., 2020).

The significant community differences and lack of morphotype overlap between the metazoan megafaunal communities on seamounts and the abyssal plain are unsurprising, given the $>1,400 \mathrm{~m}$ elevation of the study areas above the abyssal plain and significantly different sediment environments. Analysis of environmental DNA in sediments at the same sites also found that communities on the seamounts differed from the plain (Laroche et al., 2020). Dissimilarity between megafaunal communities on seamounts and nearby abyssal plains related to density and diversity was also observed in APEIs-3 and 6 (Cuvelier et al., 2020; Jones et al., in review), with some morphotypes found exclusively on the seamounts.
Abyssal hills, similar but comparatively small topographic features, result in significant changes to the seabed environment (Turnewitsch et al., 2015; Morris et al., 2016), megafaunal community structure and ecosystem function (Durden et al., 2015; Mitchell et al., 2020). Depth and substrate are important to the composition and distribution of organisms on seamounts (Tittensor et al., 2009), with species replacement observed to dominate beta diversity processes in seamount communities with depth, rather than changes to species richness (Victorero et al., 2018). The Cuvelier et al. (2020) study of multiple seamounts in the eastern CCZ similarly found reduced similarity in megafaunal communities between seamounts with larger depth differences than between those of similar depth, though the comparison was non-statistical and included both hard and soft substrates. The study areas on the seamounts in the western CCZ focused on soft sediments, thus controlling for differences between hard and soft substrate, and found a high proportion of morphotypes only on the seamounts $(61 \%$, representing $89 \%$ of individuals on the seamounts), which was likely related to both sediment texture (as described above) and depth differences. Some fauna observed exclusively on the seamounts in APEIs 4 and 7 are likely depth-limited; for example, Laetmogone sp. have been observed elsewhere at bathyal rather than abyssal depths (Tyler et al., 1985). Of the morphotypes found on both the seamounts and the abyssal plain, $45 \%$ were groups only identifiable to class or order, precluding our ability to assess their ranges specifically. Thus, it may be reasonable to exclude these morphotypes, leaving only $29 \%$ of morphotypes (representing $8 \%$ of individuals on the seamounts) found in both habitats. This low species overlap between seamounts and abyssal plain, a finding shared by Cuvelier et al. (2020), suggests low connectivity between the habitats.

Low morphotype overlap (21\%) between the seamounts in APEIs 4 and 7 is a source of community dissimilarity, and suggests that connectivity between seamounts may also be low. However, the assessment of morphotype overlap must be tempered by the fact that morphotypes were still accumulating at the two seamounts (Supplementary Material 5). The limited connectivity between seamounts sites in APEIs 4 and 7 was also reflected in environmental DNA analysis from the same sites (Laroche et al., 2020). These community differences in the seamounts in APEIs 4 and 7 may be related to the $\sim 440 \mathrm{~m}$ difference in water depths of the study areas contributing to range restriction of particular taxa. High variation in connectivity has been observed between seamounts, related to some taxa having wide distributions while others are more localised (Clark et al., 2009). Order and class-level differences between the seamounts in APEIs 4 and 7 are evident, with Asteroidea, Crinoidea, Echinoidea, and Decapoda only observed at the seamount at APEI-7, and Actiniaria, Ceriantharia, Alcyonacea, Pennatulacea, Holothuroidea, and Ophiuroidea at both seamounts, with large differences in abundances of each between seamounts. Similar higher taxonomic-level differences were observed between seamounts in APEI-3 and contract areas in the eastern CCZ (Cuvelier et al., 2020), with Alcyonacea found at all seamounts, but large differences in densities of Antipatharia, Pennatulacea, Porifera, and Echinodermata contributing to the significant 
differences in megafaunal communities observed. This apparent lack of connectivity between the seamounts observed in the western CCZ, and variation in connectivity between those studied in the east, may require additional consideration in terms of regional management and conservation planning, as seamount habitats could be impacted by plumes from mining activities on nearby abyssal plains. The high percentage of species represented by singletons, and the continuing accumulation of species at each site (Supplementary Material 5), indicate that substantially more sampling of seamounts is required to fully document biodiversity and connectivity of the CCZ seamount fauna. Undersampling is a concern at other seamounts (Cuvelier et al., 2020), which limits the evaluation of biodiversity and connectivity among seamounts and between habitats across the CCZ.

\section{Implications for Regional Management of Polymetallic Nodule Mining}

Observations of environmental and faunal conditions across the APEIs are needed to provide evidence to evaluate the design and efficacy of the regional environmental management plan for polymetallic nodule mining. The design of the APEI network aimed to conserve biodiversity and ecosystem function, and was originally planned to span the range of habitat and biological variation across the CCZ, based on modelled biophysical parameters (Wedding et al., 2013). The high diversity of megafauna observed and apparently low connectivity at the western APEIs reinforces the need for the distributed nature of the APEI network. The observations from APEIs 1, 4, and 7 provide important western end members to combine with observations from the eastern CCZ, in creating a regional picture that could be used to evaluate whether the APEI network design is suitable for its aims. Some examples of potential network evaluation perspectives using these data include:

(1) One evaluation could include adjusting the modelled variation in parameters across the CCZ to reflect ground-truthing from gathered baseline environmental information. The low values of observed polymetallic nodule and invertebrate abundance at the western APEIs, and the bathymetry collected during the DeepCCZ project expedition (Figure 1), directly address three of the biophysical parameters used in the APEI network design. The bathymetric data revealed previously unknown seamounts, suggesting that the number of seamounts used in the original design may be an underestimate.

(2) A second evaluation of the APEI network design could include assessing the suitability of these biophysical parameters as suitable proxies of the habitats, biodiversity and ecosystem function. The results of this study suggest that many of the original biophysical parameters continue to be important to the benthic assemblage at the regional scale, as the observed variations in megafaunal assemblages between the study sites in the western CCZ likely result from combined effects of environmental factors, including nodule presence and occurrence, organic matter inputs, depth, and topographic undulation on the abyssal plains. The evaluation would benefit from considering the results of habitat mapping of the region (McQuaid et al., 2020), to assist in evaluating the weighting of these parameters.

(3) Continued evaluation of whether the APEIs represent the habitats and fauna of the mined areas, could incorporate baseline environmental information from the APEIs as it becomes available. Observations from the APEIs could be used in aggregate to compare with those aggregated from contract areas, or more locally to compare with adjacent contract areas directly to determine whether they contain the same habitats and biodiversity, and any overlaps in species. Such comparisons could include syntheses of environmental or habitat parameters (Washburn et al., 2021a), biological data across multiple size classes (e.g., Washburn et al., 2021b, for macrofauna), and habitat mapping (McQuaid et al., 2020). At the contract area scale, the results of this study and those at other APEIs will be vital for spatial planning of work in the contract area in preparation of the environmental impact assessment (Durden et al., 2018; Clark et al., 2020), designation of reference zones (Jones et al., 2018), and wider environmental management (Durden et al., 2017).

Despite the need for baseline information on the APEIs, studies of these areas remain few, and limited in spatial and temporal scope. For example, the seabed areas photographed in each of our study areas encompass only $\sim 5 \times 10^{-7} \%$ of an APEI that is $1.44 \times 10^{6} \mathrm{~km}^{2}$ in area (Table 1), and whether the photographed areas represent the habitats and megafauna of the remaining portions of the APEIs is unknown. Despite the lack of areal coverage, the observed low density and high diversity of the megafaunal assemblages of the western CCZ provides important information for designing future studies across the APEIs (Supplementary Material 5), and points to the potential areal coverage required to ensure the observed area is representative of an APEI (e.g., survey design calculations in Durden et al., 2016b). The observed prevalence of rare morphotypes is particularly important to future survey design, as the detection of rare morphotypes is sensitive to the area surveyed, resulting in the need for a larger study area to document the biodiversity and assess species overlaps than in habitats with few rare morphotypes. A further factor precluding robust comparisons between APEIs and evaluation of the APEI network is the lack of consideration of temporal variation. Studies of the APEIs to date have been conducted in different seasons and years (as noted above), though some studies of APEIs have been conducted at similar times to those of adjacent exploration contract areas, facilitating comparisons (e.g., Amon et al., 2016; Vanreusel et al., 2016). Finally, the practicalities of studying the APEIs must be considered. The paucity of studies conducted at the APEIs in the western CCZ may be in part related to their inaccessibility, as they are distant from shore. Thus, a comprehensive plan to study the APEIs is needed to ensure that observations and data are captured with sufficient consideration for these spatial, temporal and practical factors to produce the necessary data for understanding patterns in the environment and fauna regionally, and for evaluating, maintaining and updating the regional management plan. 


\section{CONCLUSION}

We provide the first assessment of the megafaunal communities along with aspects of the benthic environment on the abyssal plains and on two seamounts in the APEIs of the western CCZ. Our findings suggest that megafaunal communities are low in density with high biodiversity, including many rare morphotypes. Megafaunal communities differed between abyssal plain sites, and from and between seamount communities, with minimal apparent overlap in morphotypes between these communities (but note the potential influence of small sample sizes). Densities were lower than elsewhere in the CCZ, expanding the variation in observed abundance across the region.

This study provides preliminary, but critical baseline data on these APEIs. In addition to beginning the collection of baseline information on the habitats and megafaunal assemblages of these APEIs, our results provide a western end member for any regional CCZ assessment and ground-truthed evaluation of the APEI network design. Detection of rare morphotypes is sensitive to study size, which was small relative to the area of each APEI. Their prevalence highlights the need for further sampling to cover sufficient seabed areas of these habitats, both in the APEIs and the contract areas, to understand the breadth of biodiversity, and the role of rare species in the ecosystem.

\section{DATA AVAILABILITY STATEMENT}

Photographic data used in this study are available from the Deep Sea Animal Research Center at the University of Hawai' $i$ and via the NOAA Deep-Sea Coral \& Sponge Map Portal (https: //www.ncei.noaa.gov/maps/deep-sea-corals/mapSites.htm). The original contributions presented in the study are included in the article/Supplementary Material.

\section{ETHICS STATEMENT}

Ethical review and approval was not required for the animal study because this study observed these organisms in their natural environment without interaction.

\section{AUTHOR CONTRIBUTIONS}

JMD, JCD, and CS designed the study. JMD, MP, SB, AL, AS, TW, and CS conducted the field work and collected the data. MP, SB,

\section{REFERENCES}

Amon, D., Ziegler, A., Dahlgren, T., Glover, A., Goineau, A., Gooday, A., et al. (2016). First insights into the abundance and diversity of abyssal megafauna in a polymetallic-nodule region in the eastern Clarion-Clipperton Zone. Sci. Rep. 6:30492. doi: 10.1038/srep30492

Amon, D. J., Ziegler, A. F., Drazen, J. C., Grischenko, A. V., Leitner, A. B., Lindsay, D. J., et al. (2017). Megafauna of the UKSRL exploration contract area and eastern Clarion-Clipperton Zone in the Pacific Ocean: Annelida, Arthropoda, Bryozoa, Chordata, Ctenophora, Mollusca. Biodivers. Data J. 14:e14598. doi: 10.3897/BDJ.5.e14598
AL, JCD, and AG provided taxonomic expertise. JMD, DJ, and CS planned the statistical analysis. JMD wrote the first draft of the manuscript. All authors contributed to manuscript revision.

\section{FUNDING}

This work was supported by the Gordon and Betty Moore Foundation (grant no. 5596), NOAA OAR Office for Ocean Exploration and Research (award no. NA17OAR0110209) and Pew Charitable Trusts (contract no. 30788). Support was also received from the UK Natural Environment Research Council through National Capability funding to NOC as part of the Climate Linked Atlantic Section Science (CLASS) programme (grant no. NE/R015953/1).

\section{ACKNOWLEDGMENTS}

We thank the captain and crew of the R/V Kilo Moana, the ROV Lu'ukai team, and the DeepCCZ Biodiversity Project members for their support at sea. Thanks to James Hunt (NOC) for his assistance with the laser diffraction meter, to Brian Schlining (MBARI) for his assistance in configuring VARS, to Erik Simon-Lledó for the invitation to participate in a megafaunal taxonomic workshop, and the taxonomists who assisted in identifying specimens in images: Rich Mooi (California Academy of Sciences), David Billett (Deep Seas Environmental Solutions Ltd.), Chris Kelley and Les Watling (University of Hawai'i), Antonina Kremenetskaya and Andrey Gebruk (P.P. Shirshov Institute of Oceanology). Photographic data used in this study are available from the Deep Sea Animal Research Center at the University of Hawai' $i$ and via the NOAA Deep-Sea Coral and Sponge Map Portal (https://www.ncei.noaa.gov/maps/deepsea-corals/mapSites.htm), our thanks to Virginia Moriwake for facilitating the data availability. This is contribution number 11355 from SOEST, University of Hawai'i.

\section{SUPPLEMENTARY MATERIAL}

The Supplementary Material for this article can be found online at: https://www.frontiersin.org/articles/10.3389/fmars. 2021.671062/full\#supplementary-material

Bett, B. J., and Rice, A. L. (1993). The feeding-behavior of an abyssal echiuran revealed by in-situ time-lapse photography. Deep Sea Res. I Oceanogr. Res. Papers 40, 1767-1779.

Billett, D. S. M., Bett, B. J., Reid, W. D. K., Boorman, B., and Priede, I. G. (2010). Long-term change in the abyssal NE Atlantic: the 'Amperima Event' revisited. Deep Sea Res. II. Top. Stud. Oceanogr. 57, 1406-1417. doi: 10.1016/j.dsr2.2009. 02.001

Billett, D. S. M., Bett, B. J., Rice, A. L., Thurston, M. H., Galeron, J., Sibuet, M., et al. (2001). Long-term change in the megabenthos of the Porcupine Abyssal Plain (NE Atlantic). Progr. Oceanogr. 50, 325-348. 
Bo, M., Bertolino, M., Borghini, M., Castellano, M., Covazzi Harriague, A., Di Camillo, C. G., et al. (2011). Characteristics of the mesophotic megabenthic assemblages of the vercelli seamount (north tyrrhenian sea). PLoS One 6:e16357. doi: 10.1371/journal.pone.0016357

Boschen, R. E., Rowden, A. A., Clark, M. R., Barton, S. J., Pallentin, A., and Gardner, J. P. A. (2015). Megabenthic assemblage structure on three New Zealand seamounts: implications for seafloor massive sulfide mining. Mar. Ecol. Progr. Ser. 523, 1-14. doi: 10.3354/meps11239

Clark, M. R., Durden, J. M., and Christiansen, S. (2020). Environmental impact assessments for deep-sea mining: can we improve their future effectiveness? Mar. Pol. 114. doi: 10.1016/j.marpol.2018.11.026

Clark, M. R., Rowden, A. A., Schlacher, T., Williams, A., Consalvey, M., Stocks, K. I., et al. (2009). The ecology of seamounts: structure, function, and human impacts. Annu. Rev. Mar. Sci. 2, 253-278. doi: 10.1146/annurev-marine120308-081109

Clarke, K. R. (1993). Non-parametric multivariate analyses of changes in community structure. Aust. J. Ecol. 18, 117-143.

Cuvelier, D., Ribeiro, P. A., Ramalho, S. P., Kersken, D., Martinez Arbizu, P., and Colaço, A. (2020). Are seamounts refuge areas for fauna from polymetallic nodule fields? Biogeosciences 17, 2657-2680. doi: 10.5194/bg-17-26572020

Drazen, J., Church, M., Dahlgren, T., Durden, J., Glover, A., Goetze, E., et al. (2019). Exploration of biodiversity and ecosystem structure on seamounts in the Western CCZ. Oceanogr.

Drazen, J. C., Leitner, A. B., Jones, D. O. B., and Simon-Lledó, E. (in review). Regional variation in communities of demersal fishes and scavengers across the CCZ. Front. Mar. Sci.

Durden, J. M., Bett, B. J., Billett, D. S. M., Horton, T., Morris, K. J., SerpellStevens, A., et al. (2016a). Improving the estimation of deep-sea megabenthos biomass: dimension-to-wet weight conversions for abyssal invertebrates. Mar. Ecol. Progr. Ser. 552, 71-79. doi: 10.3354/meps11769

Durden, J. M., Bett, B. J., Huffard, C., Ruhl, H. A., and Smith, K. L. Jr. (2019). Abyssal deposit-feeding rates consistent with the metabolic theory of ecology. Ecology 100:e02564. doi: 10.1002/ecy.2564

Durden, J. M., Bett, B. J., Huffard, C. L., Pebody, C., Ruhl, H. A., and Smith, K. L. (2020a). Response of deep-sea deposit-feeders to detrital inputs: a comparison of two abyssal time-series sites. Deep Sea Res. II Top. Stud. Oceanogr. 173:104677. doi: 10.1016/j.dsr2.2019.104677

Durden, J. M., Bett, B. J., Jones, D. O. B., Huvenne, V. A. I., and Ruhl, H. A. (2015). Abyssal hills-hidden source of increased habitat heterogeneity, benthic megafaunal biomass and diversity in the deep sea. . Progr. Oceanogr. 137 (Pt A), 209-218. doi: 10.1016/j.pocean.2015.06.006

Durden, J. M., Bett, B. J., and Ruhl, H. A. (2020b). Subtle variation in abyssal terrain induces significant change in benthic megafaunal abundance, diversity and community structure. Progr. Oceanogr. 186:102395. doi: 10.1016/j.pocean. 2020.102395

Durden, J. M., Lallier, L. E., Murphy, K., Jaeckel, A., Gjerde, K., and Jones, D. O. B. (2018). Environmental impact assessment process for deep-sea mining in 'the Area'. Mar. Pol. 87, 194-202. doi: 10.1016/j.marpol.2017.10.013

Durden, J. M., Murphy, K., Jaeckel, A., Van Dover, C. L., Christiansen, S., Ortega, A., et al. (2017). A procedural framework for robust environmental management of deep-sea mining projects using a conceptual model. Mar. Pol. 84, 193-201. doi: 10.1016/j.marpol.2017.07.002

Durden, J. M., Schoening, T., Althaus, F., Friedman, A., Garcia, R., Glover, A., et al. (2016b). "Perspectives in visual imaging for marine biology and ecology: from acquisition to understanding," in Oceanography and Marine Biology: an Annual Review, eds R. N. Hughes, D. J. Hughes I, P. Smith, and A. C. Dale (Boca Raton, FL: CRC Press), 1-72.

Ebert, T. (2013). "Potential use of production and biomass for life-history comparisons of sea urchins," in Echinoderms in a Changing World, ed. C. Johnson (London: Taylor \& Francis Group), 141-150.

Fock, H., Uiblein, F., Koster, F., and von Westernhagen, H. (2002). Biodiversity and species-environment relationships of the demersal fish assemblage at the Great Meteor Seamount (subtropical NE Atlantic), sampled by different trawls. Mar. Biol. 141, 185-199. doi: 10.1007/S00227-002-0804-Y

Genin, A., Dayton, P. K., Lonsdale, P. F., and Spiess, F. N. (1986). Corals on seamount peaks provide evidence of current acceleration over deep-sea topography. Nature 322, 59-61.
Gooday, A., Durden, J., and Smith, C. (2020a). Giant, highly diverse protists in the abyssal Pacific: vulnerability to impacts from seabed mining and potential for recovery. Commun. Integr. Biol. 13, 189-197. doi: 10.1080/19420889.2020. 1843818

Gooday, A. J., Bett, B. J., and Pratt, D. N. (1993). Direct observation of episodic growth in an abyssal xenophyophore (Protista). Deep Sea Res. I 40, 2131-2143.

Gooday, A. J., Durden, J. M., Holzmann, M., Pawlowski, J., and Smith, C. R. (2020b). Xenophyophores (Rhizaria, Foraminifera), including four new species and two new genera, from the western Clarion-Clipperton Zone (abyssal equatorial Pacific). Eur. J. Protistol. 75:125715. doi: 10.1016/j.ejop.2020.125715

Gooday, A. J., Holzmann, M., Caulle, C., Goineau, A. L., Jones, D. O. B., Kamenskaya, O, et al. (2017a). New species of the xenophyophore genus Aschemonella (Rhizaria: Foraminifera) from areas of the abyssal eastern Pacific licensed for polymetallic nodule exploration. Zool. J. Linn. Soc. 182, 479-499. doi: 10.1093/zoolinnean/zlx052/4554273/New-species-of-thexenophyophore-genus

Gooday, A. J., Holzmann, M., Caulle, C., Goineau, A. L, Kamenskaya, O., Weber, A. A. T., et al. (2017b). Giant protists (xenophyophores, Foraminifera) are exceptionally diverse in parts of the abyssal eastern Pacific licensed for polymetallic nodule exploration. Biol. Conserv. 207, 106-116. doi: 10.1016/j. biocon.2017.01.006

Gooday, A. J., Holzmann, M., Goineau, A. L., Pearce, R. B., Voltski, I., Weber, A. A.-T., et al. (2017c). Five new species and two new genera of xenophyophores (Foraminifera: Rhizaria) from part of the abyssal equatorial Pacific licensed for polymetallic nodule exploration. Zool. J. Linn. Soc. 183, 723-748. doi: 10.1093/ zoolinnean/zlx093/4757204

Gooday, A. J., Holzmann, M., Goineau, A.l, Kamenskaya, O., Melnik, V. F., Pearce, R. B., et al. (2018a). Xenophyophores (Rhizaria, Foraminifera) from the Eastern Clarion-Clipperton Zone (equatorial Pacific): the genus Psammina. Protist 169, 926-957. doi: 10.1016/j.protis.2018.09.003

Gooday, A. J., Sykes, D., Goral, T., Zubkov, M. V., and Glover, A. G. (2018b). ). Micro-CT 3D imaging reveals the internal structure of three abyssal xenophyophore species (Protista, Foraminifera) from the eastern equatorial Pacific Ocean. Sci. Rep. 8:12103. doi: 10.1038/s41598-018-30186-2

Gove, J. M., McManus, M. A., Neuheimer, A. B., Polovina, J. J., Drazen, J. C., Smith, C. R., et al. (2016). Near-island biological hotspots in barren ocean basins. Nat. Commun. 7:10581. doi: 10.1038/ncomms10581

Grassle, J. F., Sanders, H. L., Hessler, R. R., Rowe, G. T., and Mclellan, T. (1975). Pattern and zonation-study of Bathyal Megafauna using research submersible alvin. Deep Sea Res. 22, 457-481.

Harbour, R. P., Leitner, A. B., Ruehlemann, C., Vink, A., and Sweetman, A. K. (2020). Benthic and demersal scavenger biodiversity in the eastern end of the Clarion-Clipperton Zone-an area marked for polymetallic nodule mining. Front. Mar. Sci. 7:458. doi: 10.3389/fmars.2020.00458

Harris, P. T., Macmillan-Lawler, M., Rupp, J., and Baker, E. K. (2014). Geomorphology of the oceans. Mar. Geol. 352, 4-24. doi: 10.1016/j.margeo. 2014.01.011

Hudson, I. R., Wigham, B. D., Solan, M., and Rosenberg, R. (2005). Feeding behaviour of deep-sea dwelling holothurians: inferences from a laboratory investigation of shallow fjordic species. J. Mar. Syst. 57, 201-218. doi: 10.1016/j. jmarsys.2005.02.004

Hurlbert, S. H. (1971). Nonconcept of species diversity-critique and alternative parameters. Ecology 52, 577-586.

International Seabed Authority (2010). A Geological Model of Polymetallic Nodule Deposits in the Clarion Clipperton Fracture Zone. Kingston: International Seabed Authority.

Jones, D. O. B., Ardron, J. A., Colaco, A., and Durden, J. M. (2018). Environmental considerations for impact and preservation reference zones for deep-sea mining. Mar. Pol. 118. doi: 10.1016/j.marpol.2018.10.025

Jones, D. O. B., Yool, A., Wei, C.-L., Henson, S. A., Ruhl, H. A., Watson, R. A., et al. (2014). Global reductions in seafloor biomass in response to climate change. Glob. Change Biol. 20, 1861-1872. doi: 10.1111/gcb.12480

Jones, D. O. B., Simon-Lledo, E., Amon, D. J., Bett, B. J., Caulle, C., Clément, L., et al. (in review). Environment, Ecology, and Potential Effectiveness of an Area Protected From Deep-Sea Mining (Clarion Clipperton Zone, Abyssal Pacific).

Kahn, A. S., Pennelly, C. W., McGill, P. R., and Leys, S. P. (2020). Behaviors of sessile benthic animals in the abyssal northeast Pacific Ocean. Deep Sea Res. II Top. Stud. Oceanogr. 173:104729. doi: 10.1016/j.dsr2.2019.104729 
Kahn, A. S., Ruhl, H. A., and Smith, K. L. (2012). Temporal changes in deepsea sponge populations are correlated to changes in surface climate and food supply. Deep Sea Res. I Oceanogr. Res. Papers 70, 36-41. doi: 10.1016/j.dsr.2012. 08.001

Kamenskaya, O. E., Melnik, V. F., and Gooday, A. J. (2013). Giant protists (xenophyophores and komokiaceans) from the Clarion-Clipperton ferromanganese nodule field (eastern Pacific). Biol. Bull. Rev. 3, 388-398. doi: 10.1134/s2079086413050046

Kiriakoulakis, K., Vilas, J. C., Blackbird, S. J., Aristegui, J., and Wolff, G. A. (2009). Seamounts and organic matter-Is there an effect? The case of sedlo and seine seamounts, part 2. Composition of suspended particulate organic matter. Deep Sea Res. II Top. Stud. Oceanogr. 56, 2631-2645. doi: 10.1016/j.dsr2.2008.12.024

Kuhnz, L. A., Ruhl, H. A., Huffard, C. L., and Smith, K. L. Jr. (2014). Rapid changes and long-term cycles in the benthic megafaunal community observed over 24 years in the abyssal northeast Pacific. Progr. Oceanogr. 124, 1-11. doi: $10.1016 /$ j.pocean.2014.04.007

Lacharité, M., and Metaxas, A. (2017). Hard substrate in the deep ocean: How sediment features influence epibenthic megafauna on the eastern Canadian margin. Deep Sea Res. I Oceanogr. Res. Papers 126, 50-61. doi: 10.1016/j.dsr. 2017.05.013

Laroche, O., Kersten, O., Smith, C. R., and Goetze, E. (2020). Environmental DNA surveys detect distinct metazoan communities across abyssal plains and seamounts in the western Clarion Clipperton Zone. Mol. Ecol. 29, 4588-4604. doi: $10.1111 / \mathrm{mec} .15484$

Leitner, A. B., Durden, J. M., Smith, C. R., Klingberg, E., and Drazen, J. C. (2020a). Synaphobranchid eel swarms on abyssal seamounts: largest aggregation of fishes ever observed at abyssal depths. Deep Sea Res. I Oceanogr. Res. Papers 167:103423. doi: 10.1016/j.dsr.2020/103423

Leitner, A. B., Neuheimer, A. B., Donlon, E., Smith, C. R., and Drazen, J. C. (2017). Environmental and bathymetric influences on abyssal bait-attending communities of the Clarion Clipperton Zone. Deep Sea Res. I Oceanogr. Res. Papers 125, 65-80. doi: 10.1016/j.dsr.2017.04.017

Leitner, A. B., Neuheimer, A. B., and Drazen, J. C. (2020b). Evidence for longterm seamount-induced chlorophyll enhancements. Sci. Rep. 10:12729. doi: 10.1038/s41598-020-69564-0

Levin, L. A., and Gooday, A. J. (1992). "Possible roles for xenophyophores in deepsea carbon cycling," in Deep-Sea Food Chains and the Global Carbon Cycle, eds G. T. Rowe and V. Pariente (Dordrecht: Kluwer Academic Publishers), 93-104.

Levin, L. A., Wei, C. L., Dunn, D. C., Amon, D. J., Ashford, O. S., Cheung, W. W. L., et al. (2020). Climate change considerations are fundamental to management of deep-sea resource extraction. Glob. Chang. Biol. 26, 4664-4678. doi: $10.1111 /$ gcb.15223

Lodge, M., Johnson, D., Le Gurun, G., Wengler, M., Weaver, P., and Gunn, V. (2014). Seabed mining: international seabed authority environmental management plan for the Clarion-Clipperton Zone. A partnership approach. Mar. Pol. 49, 66-72. doi: 10.1016/j.marpol.2014.04.006

Lutz, M. J., Caldeira, K., Dunbar, R. B., and Behrenfeld, M. J. (2007). Seasonal rhythms of net primary production and particulate organic carbon flux to depth describe the efficiency of biological pump in the global ocean. J. Geophys. Res. 112. doi: 10.1029/2006jc003706

Magurran, A. E. (2013). Measuring Biological Diversity. Oxford: Blackwell Publishing.

Maldonado, M., Aguilar, R., Bannister, R. J., Bell, J. J., Conway, K. W., Dayton, P. K., et al. (2015). "Sponge grounds as key marine habitats: a synthetic review of types, structure, functional roles, and conservation concerns," in Marine Animal Forests.), eds S. Rossi, L. Bramanti, A. Gori, and C. Orejas Saco del Valle (Cham: Springer International Publishing), 1-39.

McClain, C. R., Lundsten, L., Ream, M., Barry, J. P., and DeVogelaere, A. P. (2009). Endemicity, biogeography, composition and community structure on a northeast Pacific seamount. PloS One 4:e4141. doi: 10.1371/journal.pone. 0004141

McQuaid, K. A., Attrill, M. J., Clark, M. R., Cobley, A., Glover, A. G., Smith, C. R., et al. (2020). Using habitat classification to assess representativity of a protected area network in a large, data-poor area targeted for deep-sea mining. Front. Mar. Sci. 7:1066. doi: 10.3389/fmars.2020.558860

Mewes, K., Mogollón, J. M., Picard, A., Rühlemann, C., Kuhn, T., Nöthen, K., et al. (2014). Impact of depositional and biogeochemical processes on small scale variations in nodule abundance in the Clarion-Clipperton Fracture Zone.
Deep Sea Res. I Oceanogr. Res. Papers 91, 125-141. doi: 10.1016/j.dsr.2014. 06.001

Milligan, R. J., Morris, K. J., Bett, B. J., Durden, J. M., Jones, D. O. B., Robert, K., et al. (2016). High resolution study of the spatial distributions of abyssal fishes by autonomous underwater vehicle. Sci. Rep. 6:26095. doi: 10.1038/srep26095

Mitchell, E. G., Durden, J. M., and Ruhl, H. A. (2020). First network analysis of interspecific associations of abyssal benthic megafauna reveals potential vulnerability of abyssal hill community. Progr. Oceanogr. 187:102401. doi: 10 . 1016/j.pocean.2020.102401

Morgan, N. B., Goode, S., Roark, E. B., and Baco, A. R. (2019). Fine scale assemblage structure of benthic invertebrate megafauna on the North Pacific Seamount Mokumanamana. Front. Mar. Sci. 6:715. doi: 10.3389/fmars.2019.00715

Morris, K. J., Bett, B. J., Durden, J. M., Benoist, N. M. A., Huvenne, V. A. I., Jones, D. O. B., et al. (2016). Landscape-scale spatial heterogeneity in phytodetrital cover and megafauna biomass in the abyss links to modest topographic variation. Sci. Rep. 6:34080. doi: 10.1038/srep34080

Oksanen, J., Blanchet, F. G., Kindt, R., Legendre, P., Minchin, P. R., O’Hara, R. B., et al. (2012). "vegan: Community Ecology Package". R Package Version 2.0-5 ed.

Piepenburg, D., and Muller, B. (2004). Distribution of epibenthic communities on the Great Meteor seamount (North-East Atlantic) mirrors pelagic processes. Arch. Fish. Mar. Res. 51, 55-70.

Rogers, A. (2018). The biology of seamounts: 25 years on. Adv. Mar. Biol. 79, 137-224. doi: 10.1016/bs.amb.2018.06.001

Ruhl, H. A., Ellena, J. A., and Smith, K. L. (2008). Connections between climate, food limitation, and carbon cycling in abyssal sediment communities. Proc. Natl. Acad. Sci. U.S.A. 105, 17006-17011. doi: 10.1073/pnas.0803898105

Ruhl, H. A., and Smith, K. L. (2004). Shifts in deep-sea community structure linked to climate and food supply. Science 305, 513-515. doi: 10.1126/science.1099759

Samadi, S., Schlacher, T. A., and Richer de Forges, B. (2007). "Seamount benthos," in Seamounts: Ecology, Fisheries, and Conservation, eds T. J. Pitcher, T. Morato, P. J. B. Hart, M. R. Clark, N. Haggan, and R. S. Santos (Oxford: Blackwell), 119-140.

Schlining, B. M., and Stout, N. J. (2006). “MBARI's video Annotation and Reference System," in Proceedings of the OCEANS 2006, (Piscataway, NJ: IEEE), 1-5.

Simon-Lledó, E., Bett, B. J., Huvenne, V. A. I., Schoening, T., Benoist, N. M. A., Jeffreys, R. M., et al. (2019a). Megafaunal variation in the abyssal landscape of the Clarion Clipperton Zone. Progr. Oceanogr. 170, 119-133. doi: 10.1016/ j.pocean.2018.11.003

Simon-Lledó, E., Bett, B. J., Huvenne, V. A. I., Schoening, T., Benoist, N. M. A., and Jones, D. O. B. (2019b). Ecology of a polymetallic nodule occurrence gradient: implications for deep-sea mining. Limnol. Oceanogr. 64, 1883-1894. doi: 10.1002/lno.11157

Simon-Lledó, E., Pomee, C., Ahokava, A., Drazen, J. C., Leitner, A. B., Flynn, A., et al. (2020). Multi-scale variations in invertebrate and fish megafauna in the mid-eastern Clarion Clipperton Zone. Progr. Oceanogr. 187:102405.

Simon-Lledó, E., Thompson, S., Yool, A., Flynn, A., Pomee, C., Parianos, J., et al. (2019c). Preliminary observations of the abyssal megafauna of Kiribati. Front. Mar. Sci. 6:605. doi: 10.3389/fmars.2019.00605

Smith, C., and Demopoulos, W. R. (2003). "The deep Pacific ocean floor," in Ecosystems of the World, ed. P. A. Tyler (Amsterdam: Elsevier), 179-218.

Smith, C. R., Berelson, W., Demaster, D. J., Dobbs, F. C., Hammond, D., Hoover, D. J., et al. (1997). Latitudinal variations in benthic processes in the abyssal equatorial Pacific: control by biogenic particle flux. Deep Sea Res. II Top. Stud. Oceanogr. 44, 2295-2317. doi: 10.1016/S0967-0645(97)00022-2

Smith, C. R., De Leo, F. C., Bernardino, A. F., Sweetman, A. K., and Arbizu, P. M. (2008). Abyssal food limitation, ecosystem structure and climate change. Trends Ecol. Evol. 23, 518-528. doi: 10.1016/j.tree.2008.05.002

Smith, K. L. Jr., Ruhl, H. A., Bett, B. J., Billett, D. S. M., Lampitt, R. S., and Kaufmann, R. S. (2009). Climate, carbon cycling, and deep-ocean ecosystems. Proc. Natl. Acad. Sci. U.S.A. 106, 19211-19218. doi: 10.1073/pnas.0908322106

Taboada, S., Riesgo, A., Wiklund, H., Paterson, G. L. J., Koutsouveli, V., Santodomingo, N., et al. (2018). Implications of population connectivity studies for the design of marine protected areas in the deep sea: an example of a demosponge from the Clarion-Clipperton Zone. Mol. Ecol. 27, 4657-4679. doi: $10.1111 / \mathrm{mec} .14888$

Tittensor, D. P., Baco, A. R., Brewin, P. E., Clark, M. R., Consalvey, M., HallSpencer, J., et al. (2009). Predicting global habitat suitability for stony corals on seamounts. J. Biogeogr. 36, 1111-1128. doi: 10.1111/j.1365-2699.2008.02062.x 
Turnewitsch, R., Lahajnar, N., Haeckel, M., and Christiansen, B. (2015). An abyssal hill fractionates organic and inorganic matter in deep-sea surface sediments. Geophys. Res. Lett. 42, 7663-7672. doi: 10.1002/2015GL065658

Tyler, P. A., Muirhead, A., Billett, D. S. M., and Gage, J. D. (1985). Reproductive biology of the deep-sea holothurians Laetmogone violacea and Benthogone rosea (Elasipoda: Holothurioidea). Mar. Ecol. Progr. Ser. 23, 269-277.

Vanreusel, A., Hilario, A., Ribeiro, P. A., Menot, L., and Arbizu, P. M. (2016). Threatened by mining, polymetallic nodules are required to preserve abyssal epifauna. Sci. Rep. 6:26808. doi: 10.1038/srep26808

Victorero, L., Robert, K., Robinson, L. F., Taylor, M. L., and Huvenne, V. A. I. (2018). Species replacement dominates megabenthos beta diversity in a remote seamount setting. Sci. Rep. 8:4152. doi: 10.1038/s41598-018-22296-8

Vilas, J. C., Aristegui, J., Kiriakoulakis, K., Wolff, G. A., Espino, M., Polo, I., et al. (2009). Seamounts and organic matter-is there an effect? The case of sedlo and seine seamounts: part 1. Distributions of dissolved and particulate organic matter. Deep Sea Res. II: Top. Stud. Oceanogr. 56, 2618-2630. doi: 10.1016/j. dsr2.2008.12.023

Volz, J. B., Mogollón, J. M., Geibert, W., Arbizu, P. M., Koschinsky, A., and Kasten, S. (2018). Natural spatial variability of depositional conditions, biogeochemical processes and element fluxes in sediments of the eastern Clarion-Clipperton Zone, Pacific Ocean. Deep Sea Res. I Oceanogr. Res. Papers 140, 159-172. doi: 10.1016/j.dsr.2018.08.006

Washburn, T. W., Jones, D. O. B., Wei, C.-L., and Smith, C. R. (2021a). Environmental Heterogeneity throughout the Clarion-Clipperton Zone. Front. Mar. Sci. 8:661685. doi: 10.3389/fmars.2021.661685

Washburn, T. W., Menot, L., Bonifaìcio, P., Pape, E., Błaz?ewicz, M., BribiescaContreras, G., et al. (2021b). Patterns of macrofaunal biodiversity across the Clarion-Clipperton Zone: an area targeted for seabed mining. Front. Mar. Sci. 8:250. doi: 10.3389/fmars.2021.626571
Wedding, L. M., Friedlander, A. M., Kittinger, J. N., Watling, L., Gaines, S. D., Bennett, M., et al. (2013). From principles to practice: a spatial approach to systematic conservation planning in the deep sea. Proc. R. Soc. Lond. B Biol. Sci. 280:20131684. doi: 10.1098/rspb.2013. 1684

Williams, A., Althaus, F., Clark, M. R., and Gowlett-Holmes, K. (2011). Composition and distribution of deep-sea benthic invertebrate megafauna on the Lord Howe Rise and Norfolk Ridge, southwest Pacific Ocean. Deep Sea Res. II Top. Stud. Oceanogr. 58, 948-958. doi: 10.1016/j.dsr2.2010.10. 050

Williams, A., Althaus, F., and Schlacher, T. A. (2015). Towed camera imagery and benthic sled catches provide different views of seamount benthic diversity. Limnol. Oceanogr. Methods 13, 62-73.

Yesson, C., Clark, M. R., Taylor, M. L., and Rogers, A. D. (2011). The global distribution of seamounts based on 30 arc seconds bathymetry data. Deep Sea Res. I Oceanogr. Res. Papers 58, 442-453. doi: 10.1016/j.dsr.2011. 02.004

Conflict of Interest: The authors declare that the research was conducted in the absence of any commercial or financial relationships that could be construed as a potential conflict of interest.

Copyright (c) 2021 Durden, Putts, Bingo, Leitner, Drazen, Gooday, Jones, Sweetman, Washburn and Smith. This is an open-access article distributed under the terms of the Creative Commons Attribution License (CC BY). The use, distribution or reproduction in other forums is permitted, provided the original author(s) and the copyright owner(s) are credited and that the original publication in this journal is cited, in accordance with accepted academic practice. No use, distribution or reproduction is permitted which does not comply with these terms. 